IZA DP No. 7957

A Contribution to the Empirics of Reservation Wages

Alan B. Krueger

Andreas I. Mueller

February 2014

Forschungsinstitut zur Zukunft der Arbeit Institute for the Study of Labor 


\title{
A Contribution to the Empirics of Reservation Wages
}

\author{
Alan B. Krueger \\ Princeton University \\ and IZA \\ Andreas I. Mueller \\ Columbia University \\ and IZA

\section{Discussion Paper No. 7957 \\ February 2014} \\ IZA \\ P.O. Box 7240 \\ 53072 Bonn \\ Germany \\ Phone: +49-228-3894-0 \\ Fax: +49-228-3894-180 \\ E-mail: iza@iza.org
}

Any opinions expressed here are those of the author(s) and not those of IZA. Research published in this series may include views on policy, but the institute itself takes no institutional policy positions. The IZA research network is committed to the IZA Guiding Principles of Research Integrity.

The Institute for the Study of Labor (IZA) in Bonn is a local and virtual international research center and a place of communication between science, politics and business. IZA is an independent nonprofit organization supported by Deutsche Post Foundation. The center is associated with the University of Bonn and offers a stimulating research environment through its international network, workshops and conferences, data service, project support, research visits and doctoral program. IZA engages in (i) original and internationally competitive research in all fields of labor economics, (ii) development of policy concepts, and (iii) dissemination of research results and concepts to the interested public.

IZA Discussion Papers often represent preliminary work and are circulated to encourage discussion. Citation of such a paper should account for its provisional character. A revised version may be available directly from the author. 


\section{ABSTRACT}

\section{A Contribution to the Empirics of Reservation Wages ${ }^{*}$}

This paper provides evidence on the behavior of reservation wages over the spell of unemployment using high-frequency longitudinal data. Using data from our survey of unemployed workers in New Jersey, where workers were interviewed each week for up to 24 weeks, we find that self-reported reservation wages decline at a modest rate over the spell of unemployment, with point estimates ranging from 0.05 to 0.14 percent per week of unemployment. The decline in reservation wages is driven primarily by older individuals and those with personal savings at the start of the survey. The longitudinal nature of the data also allows us to test the relationship between job acceptance and the reservation wage and offered wage, where the reservation wage is measured from a previous interview to avoid bias due to cognitive dissonance. Job offers are more likely to be accepted if the offered wage exceeds the reservation wage, and the reservation wage has more predictive power in this regard than the pre-displacement wage, suggesting the reservation wage contains useful information about workers' future decisions. In addition, there is a discrete rise in job acceptance when the offered wage exceeds the reservation wage. In comparison to a calibrated job search model, the reservation wage starts out too high and declines too slowly, on average, suggesting that many workers persistently misjudge their prospects or anchor their reservation wage on their previous wage.

JEL Classification: J30, J64, J65

Keywords: reservation wage, unemployment, unemployment duration, unemployment insurance

Corresponding author:

Andreas I. Mueller

Columbia Business School

Uris Hall 824

3022 Broadway

New York, NY 10027

USA

E-mail: amueller@columbia.edu

\footnotetext{
*We thank Bob Hall, Till von Wachter and seminar participants at Berkeley, the Richmond Fed, the U.S. Census Bureau and Columbia University for helpful comments. We are grateful to the Princeton Industrial Relations Section and National Institute of Aging (Roybal Grant P30AG024928) for financial support. This research was conducted under the terms of a memorandum of understanding with the New Jersey Department of Labor and Workforce Development, and we are grateful for their assistance and cooperation. The authors are solely responsible for the views expressed in the paper and any errors.
} 


\section{Introduction}

The sequence of reservation wages over the spell of unemployment plays a central role in search theory. Starting with the seminal contribution of Mortensen (1977), numerous papers have studied the implications of different sources of non-stationarity for the path of the reservation wage over the spell of unemployment. ${ }^{1}$ Yet, evidence on the behavior of reservation wages over the spell of unemployment remains scarce and relies mainly on cross-sectional data for those with varying lengths of unemployment at the time of the survey, which is susceptible to bias due to the evolving sample of unemployed workers over time. This paper attempts to fill this void by using repeated information on self-reported reservation wages over the course of an unemployment spell. ${ }^{2}$ Specifically, we use data from our Survey of Unemployed Workers in New Jersey, which collected weekly information on selfreported reservation wages for a period of up to 24 weeks for a sample of 6,025 Unemployment Insurance (UI) recipients in New Jersey, to examine the pattern of reservation wages over the spell of unemployment. In addition, we provide the first evidence on whether the self-reported reservation wage relative to the offered wage predicts job acceptance.

A small literature has previously examined the response of reservation wages to $\mathrm{UI}$ benefits by analyzing data on self-reported reservation wages, with mixed results. ${ }^{3} \mathrm{~A}$ burgeoning and complementary literature also infers the behavior of reservation wages from examining postemployment wages for those who are reemployed, often exploiting discontinuities in UI eligibility or duration across workers. These studies usually find small or insignificant effects of benefits on

\footnotetext{
${ }^{1}$ Mortensen analyzes the consequences of the limited duration of unemployment benefits for the optimal reservation wage path over the spell of unemployment. Other early contributions are Burdett and Vishwanath (1988), who consider learning about the job offer distribution, and Danforth (1979), who sets up a model with declining wealth over the spell of unemployment. Kasper (1967) provides early cross sectional evidence.

${ }^{2}$ Devine and Kiefer (1991) review early evidence on reservation wages and find only two studies with repeated observations of the reservation wage of the same unemployed person, but for small and selected samples. More recently, Addison et al. (2009) provide longitudinal estimates of the effect of unemployment duration on the reservation wage, using yearly observations from the European Community Household Panel for the years 19941999, and find no significant relationship between unemployment duration and the reservation wage. ${ }^{3}$ Feldstein and Poterba (1984) find a relatively large elasticity of reservation wages with respect to UI benefits, whereas DellaVigna and Paserman (2005) report a small effect of a dummy of UI receipt on the reservation wage.
} 
reemployment wages, and thus suggest that the reservation wage is relatively insensitive to $\mathrm{UI}$ benefit parameters. ${ }^{4}$ While these studies often use compelling identification strategies to estimate the effects of $\mathrm{UI}$ benefits on reemployment wages, they are potentially subject to selection bias in identifying reservation wage behavior over time because only a subset of unemployed workers are offered and accept employment, and those who do regain employment are likely to have lower (and more steeply declining) reservation wages than those who remain unemployed. The longitudinal nature of our reservation wage data allows us to overcome this selection issue when analyzing the effect of unemployment duration on the reservation wage. ${ }^{5}$

One reason why it is important to empirically model reservation wages is that, in an influential article, Shimer and Werning (2007) showed that the elasticity of the reservation wage with respect to UI benefits reflects the optimality of UI benefits. They demonstrate that the after-tax reservation wage is a sufficient statistic for an unemployed worker's welfare and show that if the pre-tax reservation wage is highly elastic with respect to UI benefits, it may be welfare improving to raise UI benefits. Based on the limited evidence available, they conclude that some estimates of the UI benefit elasticity of the reservation wage imply large welfare gains of raising $\mathrm{UI}$ benefits above the level currently available in the U.S. In this paper, we show that there is a close relationship between the decline of the reservation wage over the spell of unemployment and the UI benefit elasticity of the reservation wage and thus, we can relate our estimates of the decline of reservation wages over the spell of unemployment to Shimer and Werning's analysis of the optimal provision of UI benefits.

\footnotetext{
${ }^{4}$ Card, Chetty and Weber (2007) use a discontinuity in UI eligibility in Austria based on previous work history and find a negative but insignificant effect of 10 additional weeks of $U I$ benefits on the accepted wage. More recently, Schmieder et al. (2013) and Nekoei and Weber (2013) use an age-based regression discontinuity design, where the former find a significant but small negative effect, and the latter report a significant but small positive effect. ${ }^{5}$ Additionally, the reemployment wage reflects the reservation wage and the potential wage offer distribution and thus, even in the presence of precise estimates of the effect of UI on the accepted wage, the effect of UI on the reservation wage depends on the density of wage offers at the reservation wage and thus relies on assumptions about the dispersion of potential wage offers as well as the fraction of rejected job offers. These complications are not an issue for direct measures of the reservation wage.
} 
Our analysis in Section 2 starts by setting up a stylized partial equilibrium model, where unemployed workers draw from a stationary distribution of wage offers and face a UI benefit of limited duration. This provides a benchmark against which to judge the observed adjustment in reservation wages over the spell of unemployment. Section 3 describes the survey design and Section 4 reports results from a crosssectional analysis of reservation wages. We find no significant relationship between unemployment benefits and reservation wages, but financial circumstances such as severance payments and savings appear to be positively associated with the reservation wage. Consistent with search theory, we find that risk averse workers set lower reservation wages. Section 5 reports the main results from our longitudinal analysis. We find that reservation wages decline at a modest rate over the spell of unemployment, with point estimates ranging from 0.05 to 0.14 percent per week of unemployment, or 2.5 percent to 7 percent per year. Moreover, our results indicate that the decline in reservation wages is driven by individuals aged 51 and older, and those with savings of $\$ 10,000$ or more at the start of the survey. We find no evidence of a decline in reservation wages for those who rely exclusively on UI benefits for income support. In comparison to the stylized model, reservation wages start out too high and decline too slowly, suggesting that many workers persistently misjudge their prospects or anchor their reservation wage to their previous wage.

Section 6 analyzes the job acceptance and rejection behavior of those who received job offers. Specifically, we model the likelihood of accepting a job offer as a function of the reservation wage, the offered wage, an indicator of whether the offered wage exceeds the reservation wage, and other variables. To avoid simultaneous reporting bias, we relate the reservation wage from a previous interview to the likelihood of accepting a job offer in a subsequent period, and thus minimize possible effects of cognitive dissonance. The results suggest that the self-reported reservation wage relative to the offered wage is efficacious for predicting future job acceptance, and is a stronger predictor than the 
pre-displacement wage. Indeed, there is a discrete rise in job acceptance if the offered wage equals or exceeds the reservation wage.

Section 7 relates the empirical results in this paper to Shimer and Werning's analysis on reservation wages and the optimal level of unemployment insurance benefits. Our results on the decline of the reservation wage over the spell of unemployment imply a small UI benefit elasticity of the reservation wage and we cannot reject the hypothesis that UI benefits were set optimally during the survey period. Section 8 offers some concluding thoughts.

\section{Model}

As a benchmark against which to judge our empirical estimates, we start by providing a simple model of unemployment and reservation wages. ${ }^{6}$ The unemployed worker faces a constant arrival rate $\alpha$ of job offers, and wages $w$ are drawn from a wage offer distribution $F(w)$. Initially, the unemployed worker is assumed to have no savings, so consumption is equal to the unemployment benefit $b$ when unemployed and equal to the wage $w$ when employed. The value function $U($.$) of an unemployed$ worker is:

$U(t)=u(b(t))+\beta \max _{R}\left\{U(t-1)+\alpha \int_{R}(W(x, m=0)-U(t-1)) d F(x)\right\}$,

where $t$ is the remaining duration of the unemployment benefit $b, u($.$) is the flow utility function, \beta$ is the discount factor, $\mathrm{m}$ is the number of months employed and $W(w, m=0)$ is the value of a starting a job paying wage $w$ for newly employed workers. Benefits are assumed to last for a maximum of T periods. It is important to account for a minimum period when newly employed workers do not qualify for UI benefits, which has implications for the decline in reservation wages over the spell of unemployment. To

\footnotetext{
${ }^{6}$ We start with the canonical search model of Mortensen (1977), but abstract from endogenous search effort to focus on the reservation wage, and add an eligibility requirement for UI benefits.
} 
see this, consider the extreme case where requalification for UI benefits is instantaneous: this will lead unemployed workers to reduce their reservation wage more strongly over the spell of unemployment as working on a new job will immediately qualify them for a full spell of unemployment benefits in the event of job loss on that new job. We introduce a qualifying period by assuming that unemployed workers do not qualify for UI benefits for the first 6 months of a job spell but then re-qualify for UI. The value function for an employed worker on a job paying wage $w$ who has yet to qualify for UI benefits (i.e., $\mathrm{m}<\bar{m}$ ) is:

$W(w, m)=\mathrm{u}(w)+\beta\left[(1-\delta) W(w, m+1)+\delta \mathrm{U}(0)+\alpha_{e}(1-\delta) \int_{w}(W(x, m+1)-W(w, m+1)) d F(x)\right]$

and for a worker who has qualified for benefits (i.e., $m \geq \bar{m}$ ) is:

$W(w, \bar{m})=\mathrm{u}(w)+\beta\left[(1-\delta) W(w, \bar{m})+\delta \mathrm{U}(\mathrm{T})+\alpha_{e}(1-\delta) \int_{w}(W(x, \bar{m})-W(w, \bar{m})) d F(x)\right]$,

where $\bar{m}=6$ is the number of months it takes to re-qualify for unemployment benefits, $\delta$ is the exogenous separation probability and $\alpha_{e}$ the probability of receiving a job offer while employed. ${ }^{7}$ An unemployed worker's optimal choice is characterized by the following equation:

$W(R(t), m=0)=U(t-1)$,

which implies that the reservation wage is set so the worker is indifferent between starting a new job at the reservation wage or remaining unemployed with $t-1$ periods of benefits left. The model predicts that reservation wages will decline over the spell of unemployment as the unemployed worker approaches the point of UI exhaustion, and will remain constant thereafter, because the utility associated with not working gradually declines as benefits approach the exhaustion point.

\footnotetext{
${ }^{7}$ We assume that workers are not eligible for unemployment benefits if they quit their job.
} 
We calibrate the model to derive quantitative predictions of how much one should expect reservation wages to decline over the spell of unemployment in this simple model. In our initial calibration, we set the benefit level at the beginning of the unemployment spell to 60 percent of the previous wage, and set consumption at UI exhaustion equal to 50 percent of the previous wage. The implied 16.7 percent (10/60) drop in consumption at UI exhaustion is consistent with Gruber's (1997) estimate of the response of food consumption to UI benefits. We calibrate the model at the monthly frequency, with a discount factor $\beta$ of 0.996 (about a 5 percent annual discount rate), a job offer arrival rate $\alpha$ of 0.3 per month while unemployed and a job offer arrival rate $\alpha_{\mathrm{e}}$ of 0.1 per month if employed, and assume constant relative risk aversion (CRRA) utility with a coefficient of relative risk aversion of 2 . An employed worker may lose his job with a monthly probability of 0.02 , and the wage offer distribution is assumed to be log normal with a standard deviation of $0.30 .^{8}$

Panel (a) in Figure 1 shows the predicted decline in reservation wages over 23 months (99 weeks), which was the maximum duration of benefits during our survey period. The model implies a decline in the reservation wage relative to past wage over the spell of unemployment from 0.75 to 0.66 , which corresponds to a decline of around 0.11 percent per week of unemployment. The blue dashed line corresponds to the reservation wage if unemployment benefits last forever, while the red dashed line corresponds to the reservation wage in an environment where the consumption level is set to the same level as at UI exhaustion. Interestingly, the reservation wage declines below the red dashed line. The reason is that an unemployed worker can qualify for a new spell of unemployment benefits after a certain period and is thus willing to take a lower wage offer.

An important prediction of the calibrated model is that the decline in reservation wages over the spell of unemployment is approximately equal to the response of reservation wages to a permanent

\footnotetext{
${ }^{8}$ The standard deviation of log hourly wage offers in our sample is 0.54 , but we adjust for the fact that some of this variability is due to observed and unobserved worker characteristics. See Hall and Mueller (2013) for an estimate of dispersion for an individual job seeker using the same data, and Abowd and Kramarz (2000) for a survey of the literature on the estimation of worker fixed effects with matched employer-employee data.
} 
cessation of $\mathrm{UI}$ benefits, as the overall decline of the reservation wage corresponds approximately to the difference between the blue and the red lines. Note that it is not necessary that the reservation wage starts out at the blue line, as this depends on the likelihood of exhausting unemployment benefits: If the probability of exhausting $\mathrm{UI}$ benefits at the start of the spell is small, the reservation wage is set to the same level as in the case where benefits last forever. In contrast, if the probability of exhausting UI benefits at the start of the spell is large, the reservation wage initially is set to a lower level. However, when $\mathrm{UI}$ benefits last 99 weeks, as was the case in $\mathrm{NJ}$ at the time of the survey, the risk of exhausting the $\mathrm{UI}$ is relatively small even with a relatively low job finding probability.

Naturally, the decline of the reservation wage over the spell of unemployment depends on the consumption response to UI exhaustion as well as the degree of risk aversion. As noted, in the initial case, we calibrated the drop in consumption at UI exhaustion to be 16.7 percent relative to the previous wage and assumed a coefficient of relative risk aversion of 2 . However, it is likely that non-food consumption is more elastic and drops more strongly after $\mathrm{UI}$ benefits are exhausted. Panel (b) of Figure 1 shows the same graph as in Panel (a), except that we changed the consumption level after UI exhaustion to 40 percent of previous income instead of 50 percent. This produces a decline in the reservation wage ratio from 0.74 to 0.58 over the spell of unemployment, or 0.22 percent per week of unemployment, up to the moment of $\mathrm{UI}$ benefit exhaustion, which is twice as large as in the initial case, and probably provides a more reasonable benchmark against which to judge the actual data. ${ }^{9}$

There are many other factors that are not reflected in this simple model that probably would lead rational job searchers to hasten the pace of decline in their reservation wage over a spell of unemployment. One can categorize these additional sources into three broad categories. First, some unemployed workers have positive savings at the start of the spell, and reduce their reservation wage as

\footnotetext{
${ }^{9}$ We also simulated a version of the model where we set the coefficient of relative risk aversion to 1 and found that for the calibration in Panel (b) of Figure 1 the decline of the reservation wage was 0.18 percent per week of unemployment.
} 
they reduce their savings (see Danforth, 1979). (Note also that because a majority of unemployed workers have only a trivial amount of savings, extending the model to include savings is unnecessary for them.) A second factor involves learning about the distribution of potential wage offers or the probability of receiving a job offer (see Burdett and Vishwanath, 1988). As unemployed workers update their beliefs regarding the potential wage offer distribution or the job offer probability, they should also change their reservation wage. The updating is most likely to be negative, due to human capital loss, initial over confidence, and the adverse signaling effects of long-term unemployment or discouragement effects. ${ }^{10}$ As a consequence, the value of remaining unemployed and thus the reservation wage likely decline with unemployment duration. Finally, the psychological costs associated with unemployment appear to increase over the spell of unemployment, also increasing the cost of being unemployed. ${ }^{11}$

Our benchmark search model with a non-stationary UI benefit neglects these additional elements, and thus likely understates the pace at which rational unemployed workers would be expected to adjust their reservation wage over the spell of unemployment. For this reason, we take the prediction that reservation wages should decline by about 0.22 percent per week over a 99 week spell of unemployment benefits as a lower bound for the amount predicted by conventional models.

\section{Data and Descriptive Statistics}

We use data from our Survey of Unemployed Workers in New Jersey, in which we interviewed a sample of 6,025 unemployed workers each week for up to 24 weeks. ${ }^{12}$ The sample frame for the study was drawn with a stratified random sampling procedure from the universe of unemployed workers in

\footnotetext{
${ }^{10}$ See Kroft et al. (2013) for evidence on declining job call back rates by unemployment duration, and Krueger and Mueller (2011) for evidence on declining search intensity over the spell of unemployment.

${ }^{11}$ See Clark et al. (2008) for evidence on the psychological effects of unemployment.

${ }^{12}$ See the Appendix in Krueger and Mueller (2011) for a more detailed description of the survey. The survey data can be downloaded at http://opr.princeton.edu/archive/njui/.
} 
New Jersey as of September $28,2009 .{ }^{13}$ Individuals in the sample frame were invited to participate in the study for a period of 12 weeks, and the long-term unemployed were invited to participate for an additional 12 weeks at the end of the initial study period. Each week, participants were asked to complete a short online survey about their reservation wages and job offers, as well as their time use and job search activities. To encourage participation - as well as provide revealed preference evidence on discount factors - respondents were offered the choice between receiving a \$20 visa gift card at the start of the study or a $\$ 40$ visa gift card after twelve weeks (guaranteed regardless of participation in subsequent interviews).

The unemployment rate in NJ was stable over the survey period (October 2009 through March 2010), only fluctuating between 9.6 percent and 9.7 percent, and closely mirroring the national unemployment rate. Unemployment insurance in $\mathrm{NJ}$ is slightly more generous than in other states, replacing previous earnings by 60 percent up to a maximum benefit of $\$ 584$ in $2009 .{ }^{14}$ At the start of the survey period on October 13, 2009, the maximum duration of UI benefits was 79 weeks due to both federal and state-level extensions, up from the 26 weeks in normal times. On November 8, 2009, the federal Emergency Unemployment Compensation (EUC) program was extended by another 20 weeks, increasing the maximum duration of UI benefit receipt to 99 weeks. Benefits lapsed for 640 workers in our sample who had exhausted benefits after 79 weeks but then qualified for an additional 20 weeks of benefits when Congress extended benefits to 99 weeks. These features of the UI program provide some exogenous variability in the generosity of UI benefits during our sample period.

As discussed in Krueger and Mueller (2011), one concern with the survey is the low response rate. Only $10 \%$ of those who were contacted participated in the first interview, and respondents who

\footnotetext{
${ }^{13}$ The strata consisted of eight intervals of duration of unemployment (0-2 weeks, 10-12 weeks, 20-22 weeks, 3032 weeks, 40-42 weeks, 50-53 weeks, 60-69 weeks, 70 and more weeks at the end of September 2009) and whether an email address was on file.

${ }^{14}$ Additionally, unemployed workers may receive dependents' allowances for up to three dependents ( $7 \%$ for the first dependent and $4 \%$ for the second and third dependent), but the total of the UI benefits plus dependents' allowance may not exceed the maximum UI benefit.
} 
participated in the first survey completed only around 40 percent of the subsequent weekly interviews.

The survey data, however, contains a set of survey weights, which adjust for the sampling probability of each strata as well as non-response based on demographic characteristics such as age, gender, race, ethnicity and educational attainment for each calendar week during the survey period. Moreover, with updated UI records, Krueger and Mueller (2011) show that the Kaplan-Meier UI weekly exit rate of the respondents closely tracks that of the sample frame. In addition, we obtained access to administrative data on earnings prior to UI receipt for our sample, as well as updated administrative data on earnings in 2010 for those who were reemployed in New Jersey. Panel A in Figure 2 shows the kernel density of the prior wage for the respondents and the entire sample frame, using weights adjusting for different sampling probabilities and non-response. It is apparent from the figure that our respondent sample is slightly biased towards workers with higher wages on their previous job. ${ }^{15}$ However, when we divide the average weekly wage in 2010 by the pre-unemployment wage for those who found jobs, the ratio is 0.90 for the respondents and 0.92 for the entire sample frame. Panel B of Figure 2 shows the kernel density of this ratio for the sample frame and the respondents, which look similar for both samples. ${ }^{16}$ This suggests that, relative to their previous wage, respondents accepted similar wage offers as nonrespondents.

The reservation wage question was phrased, "Suppose someone offered you a job today. What is the lowest wage or salary you would accept (before deductions) for the type of work you are looking for?" This question is similar to the one used in the May 1976 Current Population Survey that was analyzed by Feldstein and Poterba (1984). ${ }^{17}$ In addition, the survey asked participants whether they

\footnotetext{
${ }^{15}$ It should be noted that we did not use the prior wage to construct the survey weights.

${ }^{16}$ The estimated averages are obtained by using the same weights as in Columns 3 and 4 of Table 1 in Krueger and Mueller (2011). We applied the same thresholds for trimming on our survey measure of the reservation wage: Observations with weekly wages below $\$ 100$ and above $\$ 8000$ were dropped from the sample as well as observations where the ratio of the weekly wage to the previous wage exceeded three.

${ }^{17}$ The question in the Current Population Survey of May 1976 was, "What is the lowest wage or salary you would accept (before deductions) for this type of work?"
} 
received any job offers during the last seven days, about the wage that they were offered, and whether they accepted the offer or not. Finally, we have access to administrative data on UI weekly benefit rates and wages on the prior job. As mentioned above, we also have administrative data on re-employment earnings in 2010 from payroll tax records, with the limitation that they are restricted to pay earned in New Jersey and may include earnings from part-time jobs during unemployment.

The survey contains 39,201 interviews from a total of 6,025 unemployed workers. We restrict our sample to those aged 20-65 and exclude individuals once they accept a job offer. We follow Feldstein and Poterba (1984) and focus our analysis throughout the paper on the reservation wage ratio, defined as the reservation wage divided by the previous wage, to control for individual-level heterogeneity. ${ }^{18}$ Figure 3 shows the kernel density of the log of the reservation wage ratio of the sample of unemployed workers in their first interview in the survey. ${ }^{19}$ As is evident from the graph, the cross-sectional distribution of the reservation wage ratios is close to log normal, and the mean of the log of the ratio is -0.07 and the standard deviation is $0.37 .^{20}$ Nearly 80 percent of newly unemployed workers reported a reservation wage ratio above 0.75 , the optimal level from our calibrated model, suggesting either overly optimistic expectations or systematic misreporting of reservation wages. It is possible that the minimum wage imposes a lower bound on the reservation wage, but less than one percent of the

\footnotetext{
${ }^{18}$ We compute the ratio from the weekly reservation wage over the weekly previous wages because the administrative data does not contain any information on hours. Hours worked on the last job were collected in the survey, but are likely to introduce measurement error in the measure of the previous wage. Following Feldstein and Poterba (1984), we trimmed observations with reservation wage ratios greater than 3 or smaller than 1/3. In addition, we trimmed observations with weekly reservation wages greater than $\$ 8,000$ or less than $\$ 100$ and hourly reservation wages greater than $\$ 100$ or less than $\$ 5$. This trimming procedure caused us to exclude 2,692 observations out of a total of 36,514 observations with information on the reservation wage.

${ }^{19}$ To gain further insights into the determinants of the reservation wages, Appendix Table A1 provides some Mincerian wage regressions of the log hourly reservation wage, the log hourly previous wage and the log hourly offered wage on observable characteristics. Columns 1 and 2 show that for respondents in their first interview, the coefficients on educational attainment and potential work experience are very similar for the log hourly reservation wage and the log hourly previous wage. These estimates are also similar to the values obtained when running the Mincerian wage regression in other data sets.

${ }^{20}$ The wide dispersion in the reservation wage ratio is due to both the numerator and the denominator: the standard deviation of the log weekly reservation wage is 0.52 , and the standard deviation of the log weekly previous wage is 0.63 .
} 
sample reported an hourly reservation wage that was equal to or less than the $\mathrm{NJ}$ minimum wage at the time of the survey $(\$ 7.25)$.

\section{Reservation Wages, Unemployment Insurance and Liquidity: A Cross-Sectional Analysis}

A long-standing question is the extent to which reservation wages respond to aspects of the unemployment insurance program. Feldstein and Poterba (1984) analyzed a cross-sectional sample of 2,228 unemployed workers and found that the reservation wage ratio is positively associated with the benefit replacement ratio, with a one percentage point increase in the replacement ratio associated with an increase in the reservation wage ratio of between 0.13 and 0.42 percentage points. However, as pointed out by Shimer and Werning (2007), there are several shortcomings to their approach, as the coefficient on the replacement rate is biased towards one in the presence of measurement error in the previous wage or if there is an omitted third factor, such as local labor market conditions or other statespecific effects, that may be correlated with both the reservation wage ratio and the replacement rate. Moreover, even if pre-unemployment wages are measured without error, variation in the ratio could be driven to a large extent by other sources of randomness in earnings (e.g., random match quality).

Although the main novelty of our dataset is its longitudinal nature, it also permits another look at the relationship between the generosity of unemployment insurance benefits and reservation wages. The NJ dataset has several advantages over those used in the previous literature, as the sample size is larger, the survey is tailored to UI recipients, and we have access to administrative data on preunemployment wages and UI weekly benefits, which should reduce problems associated with measurement error. To be clear, UI benefits in NJ are a strict function of earnings in the base year (the first 4 quarters of the 5 quarters preceding the start of the unemployment spell), but as pointed out by Shimer and Werning (2007), it is "possible to exploit nonlinearities in benefit schedules [...] to obtain the 
desired variation" (p. 1159). Unemployment benefits in NJ replace previous earnings by 60 percent up to a maximum benefit, which constrains a third of our sample.

The regression results in Column 1 of Table 1 show that the effect of UI benefits on reservation wages is negative but statistically insignificant, and the $95 \%$ confidence interval ranges from an elasticity of -0.16 to 0.07 , below Feldstein and Poterba's estimates. ${ }^{21}$ As a check on the specification, we estimated Probit models with a dummy equal to one if the person left UI within a month of the first interview and included the same explanatory variables as in Columns 1 and 4 of Table 1 . The coefficient on the log of the benefit rate was significant at the $5 \%$ level and the estimated elasticity ranged from -.84 to -.97 . This is very close to the estimated elasticity of the duration of unemployment to the benefit level in Meyer (1990) and in the range of the estimates surveyed in Krueger and Meyer (2002) suggesting that our sample is not unusual, at least with respect to the observed relationship between UI exit and benefits. ${ }^{22}$

As explained above, the identification of the effect of $U$ I benefits on reservation wages relies on the non-linearity of the benefit schedule and thus, one may be worried that other factors that are correlated with the previous wage may lead to biases in the estimated coefficients. ${ }^{23}$ In particular, savings are likely to be positively correlated with both the previous wage and the reservation wage, which will impart a downward bias on the estimated coefficient on the benefit variable. When we exclude all individuals with savings of $\$ 10,000$ or more in the regression reported in Column 2 , the coefficient on the log of the benefit rate becomes positive but the point estimates remain small and insignificant.

\footnotetext{
${ }^{21}$ Note that we also include a dummy for observations where earnings were top-coded at $\$ 99,999$ as our identification strategy relies on non-linearities in the benefit schedule and thus may be sensitive to the methodology of imputing earnings above the top code. See Krueger and Mueller (2011) on how earnings above the top code were imputed.

22 One should note, though, that the elasticity may be smaller in recessionary periods; see Kroft and Notowidigdo (2011) and Schmieder et al. (2012).

${ }^{23}$ If we include a fourth-order polynomial of the previous wage in the regression of Column 1 of Table 2, the effect of $\mathrm{UI}$ benefits is 0.167 but with a much larger standard error (0.229). The large increase in the standard error when controlling for a more flexible functional form suggests that the size of our cross-sectional sample is too small to implement a regression kink design as in Landais (2013).
} 
Moreover, our survey contains a rich set of controls for other measures of access to liquidity, and including them in the regressions reported in Columns 3 and 4 does not meaningfully change the estimated coefficient on the benefit replacement rate. These results are largely consistent with the literature on accepted wages, which usually finds small or insignificant effects (see footnote 4). While these studies rely on rigorous identification strategies using regression discontinuity designs, our crosssectional analysis is a useful complement as it provides direct evidence on reservation wages.

The estimated effects of several of the covariates are of interest in their own right. The estimates in Column 3 suggest that severance pay has a positive and significant effect on the reservation wage of $0.9 \%$ per $\$ 10,000$ of severance pay. The regression in Column 4 controls for additional variables such as the amount of savings in the bank account, access to $\$ 5,000$ in case of an emergency, access to at least one credit card and whether the worker's spouse has a job. In general, the sign on the coefficients of these variables tends to be in line with expectations, but the coefficients are not always significant. Notably, people with at least $\$ 100,000$ in their checking or savings account have significantly higher reservation wages, as do those with access to at least one credit card. ${ }^{24}$

The county-level unemployment rate appears to have little or no association with the reservation wage, suggesting that workers who are searching for jobs in more distressed areas do not take much account of local labor market conditions in setting their reservation wage.

Finally, we find no evidence that the reservation wage differs between individuals who chose the (delayed) \$40 over the (immediate) \$20 incentive pay, consistent with the findings of DellaVigna and Paserman (2005) who found that measures of impatience such as smoking bear no relationship to the reservation wage but instead tend to be associated with a lower intensity of job search. However, we do find that the self-reported degree of risk aversion appears to have a strong and significant effect on the reservation wage. Our regression results indicate that respondents who report themselves as the least

\footnotetext{
${ }^{24}$ See Bloemen and Stancanelli (2001) for similar evidence on the effect of wealth on the self-reported reservation wage for a sample of 1,026 unemployed workers in the Netherlands.
} 
willing to take risks compared with those who report themselves as the most willing to take risks (based on a linear 0 to 10 subjective scale) have an 11 percent lower reservation wage. ${ }^{25}$ This is consistent with search theory, as risk averse workers would much rather accept a job at a low wage than remaining unemployed and receiving UI benefits.

\section{Reservation Wages over the Spell of Unemployment}

As workers exhaust their $\mathrm{UI}$ benefits and assets, the reservation wage is expected to decline. The longitudinal nature of our data permits a stronger test of this hypothesis, as it allows us to control for heterogeneity and sample selection biases potentially present in past analyses of cross-sectional data. We start by comparing our results to Feldstein and Poterba's (1984) cross-sectional findings. Table 2 reports the average ratio of the reservation wage to the pre-unemployment wage. The first two rows are directly taken from Feldstein and Poterba, who found that, on average, the reservation wage is slightly higher than the previous wage, and that the reservation wage is only slightly lower among workers with longer durations of unemployment. The second row, which shows their results for job losers, is probably more comparable to our sample of UI recipients.

The third row reports the average reservation wage ratio using just the entry-week response to our survey to make a comparison with the cross-sectional CPS data. The results are remarkably similar, although the economic environments were markedly different in the two time periods. (The national unemployment rate in May 1976 was 7.4 percent, down from 9.0 percent a year earlier, versus 9.6 percent in NJ in 2009Q4, up from 6.5 percent a year earlier.) Across all durations, the reservation wage ratio is essentially equal to the previous wage, on average, in both samples.

${ }^{25}$ This question about risk aversion has been experimentally validated; see Dohmen, et al. (2005). 
In our cross-sectional data, the reservation wage ratio is 10 percentage points lower for workers with 50 or more weeks of unemployment than for those with less than 5 weeks of unemployment. The corresponding figure in Feldstein and Poterba is 9 percentage points.

The fourth row of Table 2 utilizes the longitudinal data. In particular, we regressed the log of the reservation wage ratio on unemployment duration and individual fixed effects, so we can examine how much the reservation wage falls as unemployment duration increases for a given set of job seekers. ${ }^{26}$ The longitudinal estimates point to an even more gradual decline in the reservation wage with unemployment duration than that found by Feldstein and Poterba. The last row of Table 2 shows the same estimate but for full-time workers only, with a slightly more pronounced decline than in the full sample. The correlation in the reservation wage in adjacent weeks was 0.96 , so at the individual level, the self-reported reservation wage was also relatively stable. (For reference, the correlation in earnings in a given period reported by individuals at different times is typically around 0.90; see Bound and Krueger, 1991.)

The top panel of Figure 4 shows the average reservation wage ratio by duration of unemployment for each of the sampled cohorts. The bottom panel shows the same graphs after removing individual means. Both of the reservation wage ratio graphs display little tendency for the reservation wage to decline over the spell of unemployment. A comparison of the cross-section to the longitudinal estimates suggests that, if anything, the cross-sectional estimates slightly overstate the decline in reservation wages over the duration of unemployment, contrary to the expectation that those with relatively low reservation wage ratios would return to work sooner than those with relatively high reservation wages, all else equal.

This conclusion is also borne out in the regression results presented in Table 3a, which regress the log reservation wage ratio on unemployment duration and various other variables. Columns 1 and 2

\footnotetext{
${ }^{26}$ Specifically, we used the fixed effects estimates from Column 3 of Table 3a and used the midpoint of each category to predict the log reservation wage ratio, and then exponentiated.
} 
show a gradual decline in the reservation wage relative to the pre-unemployment wage over the spell of unemployment, and the fixed effects estimates in Columns 3 and 4 indicate a statistically insignificant and trivially small change in the reservation wage as unemployment duration increases. Moreover, the reservation wage appears insensitive to periods of lapsed benefits before and after the point of exhaustion, and is unchanged after the November 8th extension of benefits from 79 to 99 weeks.

The right part of Table 3a provides additional estimates of the fixed effects specification for various subsamples. For those with $\$ 10,000$ in savings or more, or over age 50 , we find a statistically significant, negative relationship between the reservation wage relative to previous pay and the duration of unemployment. ${ }^{27}$ For those who were both older than 50 and had more than $\$ 10,000$ in savings at the start of the study, a spell of unemployment of 25 weeks is estimated to have reduced the reservation wage by 10 percent. The finding that the reservation wage is more sensitive to unemployment duration for those with some savings at the start is consistent with the idea that as workers draw on their assets during a spell of unemployment, they become less selective about which job they would accept. The apparent willingness of older workers to lower their reservation wage the longer they are unemployed is consistent with the view that job search is an investment: the cost of accepting a lower paying job is less for those who plan to spend less time in the labor market. Many older workers apparently gradually realize that they cannot find a job that pays as well as they expected and thus adjust their reservation wage downwards, whereas younger workers are willing to maintain their reservation wage longer because it is more costly for them to accept a low paying job.

As a robustness check, we estimated the same regressions but for workers who indicated that they were looking for full-time work only. The results in Table $3 \mathrm{~b}$ for this subsample are similar to those in Table 3a, but show a statistically significant coefficient on unemployment duration, with the size of the coefficient nonetheless relatively small. The results in Column 3 indicate that for full-time workers, the

\footnotetext{
${ }^{27}$ In the entry survey, individuals with a checking, savings or money market account were asked how much savings they had.
} 
reservation wage declines by 3.4 percent over a 25 -week period. Finally, we also estimated a separate set of regressions where we excluded the 11 percent of unemployed workers who indicated that they expect to be recalled to their previous employer and the results in Tables $3 a$ and $3 b$ were very similar.

It is not possible to separately identify the effect of calendar time and the effect of unemployment duration on the reservation wage as both are perfectly collinear once we control for individual fixed effects. In particular, one may worry that seasonal factors or the state of the business cycle could confound duration effects. However, there are a number of reasons that lead us to suspect calendar time exerts little, if any, effect, apart from duration of unemployment. First, in contrast to search intensity, the reservation wage is unlikely to be influenced by seasonal factors such as holidays, as accepting a job at a low wage has a large opportunity cost in terms of foregone earnings over the entire duration of the job whereas a lower search effort only postpones job finding. Moreover, our results remain essentially unchanged if we drop observations during the last two weeks of November and the last two weeks of December, encompassing Thanksgiving and Christmas. Second, as mentioned, the unemployment rate in New Jersey was high but stable over the survey period: it remained in the narrow range of $9.6 \%$ to $9.7 \%$ over the entire survey period, and did not fall below 9.5\% until December 2010. Finally, when we added the county-level unemployment rate in our fixed effect regressions in Tables 3a and $3 b$, the size and (in)significance of the coefficient on duration remained unaffected. The coefficient on the county unemployment rate was negative but insignificant. Overall, this suggests that temporal factors related to the business cycle or holidays have not affected the estimated modest effect of unemployment duration on the reservation wage.

The relatively modest decline in reservation wages is hard to reconcile with the calibrated search model, especially for those who lack personal savings. 


\section{Other Considerations}

After eliciting the reservation wage, the questionnaire asked, "How many minutes a day would you be willing to commute if you were offered a job at that salary?" Table 4 reports estimates of the same type of models as in Table 3, using commuting time as the dependent variable in place of the reservation wage. We find a statistically significant effect of unemployment duration on the willingness to accept a longer commute to work, but the relationship is modest. A 25 week increase in unemployment is associated with only a 2.3 minute increase ( 5 percent of the average) in the amount of time individuals said they would be willing to travel to work in our fixed effects models. Thus, as a practical matter, based on their responses, job seekers do not seem particularly willing to accept a job that requires a longer commute as their duration of unemployment increases.

The survey also asked the respondents an open-ended question on what type of job/occupation they were looking for. ${ }^{28}$ The question was asked before asking about the reservation wage. We imputed the average wage for each of the occupations indicated in the open ended questions based on the average wage by occupation in the outgoing rotation group data in the CPS for the years 2005-2009. We define the occupational reservation wage as the occupation paying the lowest wage among all those listed in the answer to the open ended question. Table 5 shows the same type of regressions as in Tables $3 a$ and $3 b$ but using the log of the occupational reservation wage as the dependent variable. The results in Column 3 show a significant but quantitatively small decline of the "occupational reservation wage" over the spell of unemployment. Over a 25 week period, the occupational reservation wage is predicted to decline by about 3 percent. This indicates that unemployed workers only slightly reduce their

\footnotetext{
${ }^{28}$ The exact wording was "Please describe in a few words the type of work you are looking for (for example: Electrical engineer, stock clerk, typist, farmer, ...)." The coding of this question into three-digit occupational codes was performed by trained coders at the University of Wisconsin Survey Center who have extensive experience with occupational coding based on work with the Wisconsin Longitudinal Survey. There were 35,166 records and 15,506 unique job titles associated with this item. The survey center produced occupational codes first according to the CEN2000 schemes and then converted them into the corresponding SOC codes.
} 
occupational aspirations over the spell of unemployment, and the size of the effect is close to our estimate of the decline in the self-reported reservation wage.

Finally, an important question is whether the reservation wage falls around the time of UI benefit exhaustion. Column 4 in Tables 3 to 5 includes a dummy for having temporarily lapsed benefits in the period prior to the benefit extension of November 8, a dummy for having exhausted benefits (the full 99 weeks) and dummies for 1-4 weeks, 5-8 weeks and 9-12 weeks prior to exhaustion. ${ }^{29}$ The estimated coefficients are small and insignificant, showing that there is no acceleration in the decline of reservation wages before the UI exhaustion point. Figure 5 illustrates this point as well by displaying that the reservation wage ratio in the weeks prior to and after exhaustion, after removing individual fixed effects. The graphs show that the ratio is stable in the weeks before exhaustion, in contrast to the predictions of our calibrated model in Section 2, which shows a steeper drop in the reservation wage in the weeks prior to the exhaustion of UI benefits.

For each individual who reported a reservation wage on three or more occasions, we computed the unemployment duration-reservation wage gradient. Figure 6 presents a histogram of these individualspecific slopes. The slopes have a large mass at zero, and a mean of -.06 percent per week, very close to the fixed effects estimate for the full sample in Table 3a. Only one third of the slopes are less than -0.24 percent per week, the benchmark from our second calibration exercise. The standard deviation is sizable ( 3.8 percent), although it shrinks by about a quarter if we adjust for the fact that each slope is measured with sampling error. ${ }^{30}$ Overall, these results point to considerable heterogeneity, and a sizable proportion of individuals who are reluctant to reduce their reservation wage despite extended spells of unemployment.

\footnotetext{
${ }^{29}$ The exhaustion date is measured as the date of the last UI payment for those who exhausted all benefits, and as the potential date of $\mathrm{UI}$ exhaustion for those who found a job and exited UI before exhaustion.

${ }^{30}$ To make this adjustment, we subtracted off the average sampling variance of the individual slopes from the variance across the slopes.
} 


\subsection{Sources of Support}

Our findings raise the question of why reservation wages do not fall more steeply over the spell of unemployment, given that they seem to fall strongly for those with high initial savings. However, it is important to realize that relatively few workers in our sample entered unemployment with a significant amount of savings. Among those with less than three months of unemployment duration, 86 percent reported having savings of less than $\$ 10,000$ of savings, and 57 percent indicated that they had no savings at all. The survey also collected information on whether unemployed workers could raise $\$ 5,000$ in the following week in the event of an emergency, and only 23 percent of those unemployed for less than 3 months responded affirmatively. ${ }^{31}$

The question of access to $\$ 5,000$ emergency funds was collected on a weekly basis, so we can examine how access to liquidity evolved over the spell of unemployment, controlling for individual effects. The results in Column 1 of Table 6 show that the regression coefficient on duration of unemployment is significant at the $5 \%$ level, but the size of the coefficient is relatively small: an additional 25 weeks of unemployment is associated with a 5 percentage point increase the likelihood of being liquidity constrained according to this measure. This decrease is mostly driven by the decline in savings and the selling of stocks as can be seen in the regressions in Columns 2-6 of Table $6 .{ }^{32}$ Interestingly, borrowing from family and friends does not seem to be a close substitute for savings, as it does not compensate for the reduced access to $\$ 5,000$ through savings and selling of stocks (indeed the regression coefficient is negative, though not significant). Overall, these results suggest that financial circumstances only change modestly over the spell of unemployment as many unemployed workers are

\footnotetext{
${ }^{31}$ Among the minority of individuals who said they could raise $\$ 5,000$, the most common method was by accessing their checking, savings or money market account; fewer than 2 percent said they could use a credit card. See also Lusardi et al. (2011) who find in a survey fielded in 2009 that 50 percent of Americans could either certainly or probably come up with $\$ 2,000$ in 30 days, compared to 31 percent of unemployed individuals.

${ }^{32}$ The decline in savings and the selling of stocks account for about $75 \%$ of the reduced access to $\$ 5,000$, as one can easily see by dividing the regression coefficient on unemployment duration in Columns 2-6 by the regression coefficient on duration in Column 1.
} 
already financially constrained at the beginning of their unemployment spell. At the same time, these results heighten the question of why unemployed workers do not adjust their reservation wage more strongly, as they have no or only little access to savings which they could use to smooth their consumption after exhausting UI benefits.

\section{Validating Reservation Wages: Evidence from Job Offers and Acceptances}

For each week, the survey contains information on whether individuals received a job offer in the previous week, the number of job offers received, the wage offered, and whether the job was accepted or rejected. In the case of multiple job offers, the survey collected the wage of the best offer in the previous week. Among our sample of those aged 20-65, we have information on the wages of 1,499 job offers. Some 61.6 percent of job offers were accepted, 16.6 percent were rejected, and in the remaining 21.8 percent of cases the respondents were undecided. The survey did not collect information in subsequent interviews about the acceptance of earlier offers for which the respondent was undecided, but fortunately, we have access to administrative data and can test the extent to which the rate of UI exit in the weeks following the interview was similar among those who indicated that they accepted a job offer and those who indicated that they were undecided. We find that among those who accepted a full-time offer, $46 \%$ exited UI within one month and remained off the program, compared to $5 \%$ for those who rejected the offer and $26 \%$ for those who were undecided. ${ }^{33}$ Thus, the undecideds are an intermediate group.

\footnotetext{
${ }^{33}$ We focus here on full-time offers because unemployed workers in NJ may work part-time and still receive UI benefits. There are two main reasons why an accepted full-time offer does not lead to early UI exit: First, it may lead to Ul exit but after 1 month. We focus on 1 month because otherwise, the analysis is confounded by the presence of other offers. Second, we measure early UI exit by the most recent date of UI payment (as of September 10, 2010) and thus, potentially miss intermittent spells of employment.
} 
Past studies have not been able to assess the validity of self-reported reservation wage data because they only had access to cross-sectional data. ${ }^{34}$ Tables $7 \mathrm{a}$ and $7 \mathrm{~b}$ present evidence of the likelihood that a worker accepts a job offer, depending on whether the offered wage was above or below the reservation wage. To avoid possible reporting bias due to cognitive dissonance, the reservation wage is taken from the most recent prior survey and is therefore not contemporaneous with the report on whether the job offer was accepted or rejected. The reservation wage and the offered wage, which could be reported in different time units (i.e., hourly wage versus weekly salary), were both converted into hourly earnings, which introduces some noise because the hours data entail some measurement error.

For the full sample, workers are 24 percentage points more likely to accept an offer that equals or exceeds the reservation wage than one that is below it, and 13 percentage points more likely to reject an offer that is below the reservation wage than one that equals or exceeds it. If we restrict the sample to offers of full-time jobs, the predictive power is somewhat stronger: workers are 30 percentage points more likely to accept offers that equal or exceed the reservation wage than one that is below it. The fact that 44 percent of the respondents accepted a job that paid less than the stated reservation wage suggests that the reservation wage is not a perfect measure, but it should be borne in mind that there is some noise in both the reservation wage and the offered wage because of measurement errors in the hours data. Moreover, non-wage job characteristics such as commuting distance or fringe benefits are also an important factor in the decision to accept an offer. If these characteristics are not perfectly reflected in the wage offered, we will observe acceptance of some offers that are below the reservation wage and rejection of some offers that exceed the reservation wage. Table 8 provides some further insight, by reporting the reason for rejecting a job offer. As would be expected, inadequate pay/benefits

\footnotetext{
${ }^{34}$ Holzer (1986) provides some indirect evidence by showing that reservation wages in a given year are related to the subsequent duration of nonemployment and wages in the NLS-Y.
} 
is an important factor in the decision to reject offers below the reservation wage, whereas unsuitable working conditions and transportation problems are more important in the decision to reject offers paying more than the reservation wage, though the sample size is too small to draw strong inferences on the relative importance of non-wage job characteristics.

Despite measurement error and non-wage amenities, Tables $7 \mathrm{a}$ and $7 \mathrm{~b}$ suggest that the reservation wage has predictive power for the likelihood of accepting an offer. To further assess the predictive power of reservation wages, Figure 7 plots the probability of accepting a job (from a locally weighted regression) against the ratio of the job offer to the lagged value of the reservation wage. The figure shows that the likelihood of accepting a job offer increases with the reservation wage ratio, but not monotonically so. There seems to be a jump when the offered wage equals the reservation wage and a small dip thereafter. The reason for the jump is that there is a large mass point of job offers that pay exactly the reservation wage (around $13 \%$ of job offers; see Figure 8 ). When we exclude observations where the offered wage equals the reservation wage, the acceptance probability monotonically increases with the ratio (see the dashed line on Figure 7).

There are several potential explanations for the mass point of offers at the reservation wage, some of which we can rule out. First, unemployed workers may have had some information about a potential wage offer in the previous interview when they reported their reservation wage. However, we find that even for those offers where the most recent reservation wage was reported more than four weeks earlier, the percentage of wage offers equaling the reservation wage was $9 \%$. Second, some unemployed workers expect to be recalled to their previous employer, and thus may set the reservation wage equal to the wage at their previous job. But 11 percent of those not expecting to be recalled reported a reservation wage exactly equal to the offered wage, so this cannot be the explanation either. Another possible explanation is that some unemployed workers search in labor markets with an extremely tight dispersion of potential wages. Lastly, it is possible that employers have some 
information regarding the unemployed worker's reservation wage, which would have important consequences for the unemployed worker's incentives to search. If a fraction of employers know and thus offer the reservation wage, unemployed workers have less of an incentive to search as these employers capture the entire surplus. In the limit, when all firms offer workers their reservation wage, unemployed workers have no incentive to search, the famous paradox raised by Diamond (1971).

Table 9 presents probit models where the dependent variable is 1 if an offer has been accepted and 0 if it has been rejected or a decision has not yet been made. ${ }^{35}$ The first column indicates that workers are more likely to accept jobs that offer higher wages, less likely to accept a job if their reservation wage is higher, and also more likely to accept part-time jobs. These regression results are in line with Figure 7 and show that the likelihood of accepting a job offer is driven by both variation in the offered wage and variation in the reservation wage. Column 2 introduces a dummy variable that equals one if the hourly offered wage exceeds the hourly reservation wage, and zero otherwise. The results show that this threshold has a significant impact on the likelihood of accepting a job offer, although the interaction between part-time job status and being above or below the reservation wage indicates that the reservation wage cutoff does not predict an acceptance of part-time jobs. The value of the reservation wage itself does not predict whether a job is accepted when a binary indicator of whether the reservation wage exceeds the offered wage is included in Column 2. The value of the offered wage, however, has predictive power conditional on whether the wage exceeds the reservation wage. One interpretation of the latter finding is that jobs that offer a higher wage can compensate for undesirable conditions that are not adequately reflected in the reservation wage (e.g., commuting distance), and thus, whether the reservation wage exceeds the offered wage is not a sufficient statistic for job

\footnotetext{
${ }^{35}$ Note that we coded offers where job seekers were undecided as zeros, because we estimated the fraction of rejections to be substantial for undecided cases as opposed to cases where the job seeker reported his decision. The probit estimates were qualitatively unchanged if we excluded observations in which the respondent was undecided as to whether accept or reject the job offer; these results are available on request.
} 
acceptance or rejection. Nonetheless, the binary indicator of whether the reservation wage exceeds the offered wage is a strong predictor of job acceptance or rejection.

Recall that, on average, the reservation wage is close to the previous wage. If we use the previous wage in place of the reservation wage, however, the probit equation does not predict job acceptance as well as if we use the reported reservation wage (compare Columns 2 and 3 of Table 9). ${ }^{36}$ Moreover, if we include a pair of indicators for whether the reservation wage and the previous wage exceed the offered wage in the same equation, the reservation wage indicator has the expected sign and is statistically significant at the $1 \%$ level, while the coefficient on the previous wage indicator is about half as large and insignificant with a t-ratio of 1.5 (see column 4). These results suggest that the reservation wage captures more information than the previous wage. Furthermore, Column 5 indicates that savings and unemployment duration do not predict job acceptance conditional on the reservation wage. Because the reservation wage should be a sufficient statistic for workers' requirements, factors that affect their financial predicament or duration of job search should be irrelevant conditional on the reservation wage. The probit estimates are consistent with this prediction. Finally, the results in Column 6 show that our results remain unaffected if we control for demographic characteristics, such as age, education, gender, marital status, race and ethnicity, as well as the log of the hourly previous wage.

Despite the predictive power of the reservation wage, close to half of those who were offered a job paying less than their reservation wage accepted it. As mentioned, these cases could represent measurement errors (e.g., because of errors in work hours), or weaknesses in the reservation wage data - or in the reservation wage concept itself. In Table 10, we estimate probit equations to examine factors that predict the likelihood of accepting a job that pays less than the reservation wage for the subset of searchers who were offered such jobs. The very long-term unemployed (79 weeks or longer) were more

\footnotetext{
${ }^{36}$ The estimates in Table 9 do not adjust the previous wage for inflation. Interestingly, the nominal previous wage in relation to the offered wage is a stronger predictor of job acceptance than the real previous wage in relation to the offered wage, suggesting that some workers anchor their reservation wage on the nominal value of their previous wage.
} 
likely to accept jobs that paid below their stated reservation wage, although duration of unemployment did not matter for those who were unemployed less than 79 weeks. In addition, those who rated themselves as very willing to take risks were less likely to accept jobs that paid below the reservation wage, but those who took the immediate $\$ 20$ incentive payment over the delayed $\$ 40$ payment were not more likely to accept such job offers. Lastly, less educated workers and African Americans were less likely to accept jobs offering less than the reservation wage. These results suggest that the mispredictions of the reported reservation wage are not random, although there is little evidence of systematic bias by unemployment duration for workers who are unemployed less than 79 weeks.

To further assess the magnitude of any bias in the reservation wage for the very long-term unemployed, we estimated a linear regression model of the difference between the accepted wage and the lagged reservation wage, including the same controls as above. Columns 3 and 4 of Table 10 report the results. Surprisingly, the log difference between the accepted and reservation wage is not significantly lower for the long-term unemployed, despite their higher likelihood of accepting a job below the reservation wage. The reason for this finding is that, for those unemployed 79 weeks or longer, the likelihood of rejecting a wage offer above the reservation wage is also higher. Indeed, when we estimate the same regression as in Columns 1 and 2, but for rejecting a job offer equal to or greater than the lagged reservation wage, we find that this likelihood is around 17 percent higher for those with 79 weeks of unemployment or more. We interpret this as evidence that, for the very long-term unemployed, the reservation wage is not necessarily a biased indicator, but rather that it is a noisier signal of the true underlying reservation wage.

\section{Implications for the Optimal Level of UI Benefits}

We relate our empirical results to the analysis of Shimer and Werning (2007), who derived a sufficient statistic for the optimal provision of UI benefits. A key advantage of their approach is that it 
does not rely on preference parameters such as the degree of risk aversion or the economic environment in terms of insurance markets. The authors show that if unemployment benefits $b$ and employment taxes $\tau$ are at the optimal level (denoted by the asterisk), then

$R_{b}\left(b^{*}, \tau^{*}\right)=u r\left(b^{*}, \tau^{*}\right)\left(1+\frac{\varepsilon_{u r, b}\left(b^{*}, \tau^{*}\right)}{1-u r\left(b^{*}, \tau^{*}\right)}\right)$

where $R_{b}\left(b^{*}, \tau^{*}\right)$ is the responsiveness of the pre-tax reservation wage to the unemployment benefit, $\operatorname{ur}\left(b^{*}, \tau^{*}\right)$ is the unemployment rate and $\varepsilon_{u r, b}\left(b^{*}, \tau^{*}\right)$ is the elasticity of the unemployment rate with respect to the level of UI benefits. They derive their formula from a model where the unemployment insurance agency chooses actuarially fair unemployment benefits $b$ and employment taxes $\tau$ to maximize the worker's welfare subject to a balanced budget constraint. Their main insight is that the after-tax reservation wage is a sufficient statistic for the unemployed worker's welfare, both in an environment where workers are hand-to-mouth consumers and in an environment where they have savings. Therefore, maximizing an unemployed worker's welfare is equivalent to maximizing her aftertax reservation wage. The optimal UI formula (5) reflects this intuition and equates the responsiveness of the pre-tax reservation wage to $\mathrm{UI}$ benefits to the additional tax cost of the increase in UI benefits, which relies on the elasticity of the unemployment rate with respect to the level of UI benefits. Their result implies that if the pre-tax reservation wage is sufficiently responsive in the level of UI benefits, then it is welfare increasing to raise $\mathrm{UI}$ benefits, as the additional benefit of raising $\mathrm{UI}$ benefits outweighs the additional cost. Based on Meyer (1990), who finds that a 1 percent increase in unemployment benefits reduces the job finding hazard by $0.88^{37}$, and an average unemployment rate in NJ of $9.6 \%$ over

\footnotetext{
${ }^{37}$ Shimer and Werning also rely on Meyer's estimate. As reported in Section 4, when we estimate the elasticity of the job finding hazard to UI benefits in our data, we similarly find estimates ranging from 0.84 to 0.97 .
} 
the baseline sample period, we estimate $\varepsilon_{u r, b}\left(b^{*}, \tau^{*}\right)$ to be $0.8 .^{38}$ The right-hand side of equation (5) thus gives the value of 0.18 . Shimer and Werning find a value of 0.12 for the right-hand side of equation (5), as they use the average unemployment rate over the years 1948-2005, but our welfare calculations are only marginally affected if we used their estimate instead. ${ }^{39}$

Table 11 reports our estimates of the responsiveness of the reservation wage to the level of $\mathrm{UI}$ benefits. The estimates in rows 2 and 3 are based on our cross-sectional regressions, which identify the effect of UI benefits on the reservation wage through the non-linearity in the benefit schedule, whereas the estimates in rows 4 to 7 are based on the estimated decline of reservation wages over the spell of unemployment. The reservation wage is likely to decline over the spell of unemployment for reasons other than the potential exhaustion of $\mathrm{UI}$ benefits and thus the decline of the reservation wage over the spell of unemployment is an upper bound estimate of $d R / d b$. Note also that the decline over the spell of unemployment does not identify the marginal effect of $b$ on $R$, but rather the effect of reducing $b$ from the level currently available to zero. However, in our calibration exercise in Section $2, R$ is approximately linear in consumption during unemployment, suggesting that the effect on $R$ of a decline of $b$ to zero is closely related to the marginal effect.

Although most of the point estimates of $d R / d b$ in Table 11 are smaller than the value of the righthand side of equation (5), the confidence intervals for the welfare gain from an increase in benefits all contain 0 , implying that optimality of benefits cannot be rejected. The point estimate for the sample of full-time job seekers implies a small welfare gains from raising UI benefits, but this is an upper bound as the estimate also reflects the effect of unemployed workers drawing down savings over the spell of

\footnotetext{
${ }^{38}$ The estimate is based on the approximation that $\varepsilon_{u r, b} \approx(1-u r) h_{u r, b}$, where $h_{u r, b}$ is the job finding hazard rate.

${ }^{39}$ If we use more recent estimates of the duration elasticity by Kroft and Notowidigdo (2011), who find that the duration elasticity is reduced in times of high unemployment, we also get a value of the right-hand side of equation (5) of 0.12 . For the purpose of this calculation, we used a duration elasticity of 0.267 , which corresponds to Kroft and Notowidigdo's preferred estimate evaluated at a 70 percent increase in the unemployment rate relative to the pre-recessionary period (i.e., assuming an increase of the unemployment rate from 5.6 to 9.6 percent).
} 
unemployment. While we cannot reject the hypothesis that UI benefits in NJ are at the optimal level, our results are in contrast to the estimate implied by Feldstein and Poterba (1984) for the sample of job losers, which, as Shimer and Werning emphasized, imply large welfare gains from raising UI benefits. It is important to bear in mind, however, that benefits were more generous than usual during our sample period.

\section{Conclusion}

This paper presents new evidence on reservation wages over the spell of unemployment, using longitudinal data from weekly interviews of unemployed workers. Our findings suggest that reservation wages decline at a modest rate over the spell of unemployment, and that the decline is driven by older individuals and those with non-negligible savings. In particular, those with more than $\$ 10,000$ in liquid assets at the start of the study were more likely to lower their reservation wage over the course of their spell of unemployment, as compared to those with less savings to start with. This finding suggests that people treat time-limited government social insurance benefits differently than their own personal savings. In contrast to the calibrated search model which provides a benchmark for our estimates, we find that reservation wages start out too high and decline too slowly.

Indeed, our results suggest that unemployment insurance only has a limited impact on reservation wages. The calibrated model presented in this paper suggests that the decline of reservation wages over the 99 weeks of UI eligibility is roughly equal to the response of reservation wages to a permanent reduction of the $\mathrm{UI}$ replacement rate from 0.54 (the average in our sample) to a zero replacement rate. Our estimates imply that a decline of the reservation wage of between 5 and 13 percent over a period of 99 weeks, thus, at best, suggests a modest effect of UI benefits on reservation wages. A small response of reservation wages to $\mathrm{UI}$ benefits is also consistent with findings from our cross-sectional analysis, which finds no significant relationship between unemployment benefits and reservation wages, and the 
finding that reservation wages did not increase significantly in the weeks after the extension of UI benefits from 79 weeks to 99 weeks. These findings - read in the light of Shimer and Werning's optimal UI formula - challenge their tentative conclusion that it may be welfare improving to increase UI benefits beyond the currently available level.

It remains an open question why the reported reservation wage declines at a relatively modest rate over the spell of unemployment, particularly among those who have only minimal or no savings to cushion the drop in consumption at UI exhaustion. One possibility is that unemployed workers rely on other forms of insurance, such as family or friends, and thus experience a limited drop in consumption at the point of UI exhaustion. An alternative explanation, however, is that unemployed individuals face little dispersion in potential wage offers and thus may have little scope for reducing their reservation wage, even if the drop in consumption at UI exhaustion is large. (In our calibration exercise, however, reducing the standard deviation of log wage offers from 0.30 to 0.20 only trivially affects the predicted decline in the reservation wage.) Finally, it is possible that many job seekers anchor their reservation wage on their previous wage or are persistently over confident about their prospects, which causes them to set their reservation wage too high and to reduce it too slowly compared to the optimal rate predicted by a search model. Distinguishing among these different explanations seems of primary importance for future research. ${ }^{40}$

Our results are also in contrast with a recent paper by Brown et al. (2011), which found that in an experimental setting with a stationary environment, subjects' reservation wage declined strongly over time. The authors explain their novel finding with "non-stationary subjective costs" of time spent searching. While it is possible that the unemployed workers in our sample face increasing costs of remaining unemployed, our estimates of the decline of reservation wages over the spell of unemployment suggest at best a limited impact of these subjective costs on the reservation wage.

\footnotetext{
${ }^{40}$ See Hornstein et al. (2011) and Hall and Mueller (2013) for a recent discussion of wage dispersion in search models.
} 
Similarly, our estimates point towards a small degree of updating on the potential wage offer distribution and/or the likelihood of receiving a job offer, as this should contribute towards a downward sloping path of the reservation wage over the spell of unemployment.

Lastly, our finding that the lagged reservation wage predicts job acceptance or rejection is an encouraging result for research based on self-reported reservation wages, as is the finding that the reservation wage conveys information beyond that in the previous wage. Including a question on unemployed workers' reservation wages in ongoing labor force surveys would thus seem to be a useful addition to existing labor market indicators. 


\section{References}

[1] Abowd, John M., Francis Kramarz, David N. Margolis and Kenneth R. Troske, 2001."The Relative Importance of Employer and Employee Effects on Compensation: A Comparison of France and the United States," Journal of the Japanese and International Economies, vol. 15(4), pp. 419-436.

[2] Addison, John, Mário Centeno and Pedro Portugal, 2009. "Do Reservation Wages Really Decline? Some International Evidence on the Determinants of Reservation Wages," Journal of Labor Research, vol. 30(1), pp. 1-8.

[3] Bloemen, Hans G. and Elena G.F. Stancanelli, 2001. "Individual Wealth, Reservation Wages, and Transitions into Employment," Journal of Labor Economics, vol. 19(2), pp. 400-439.

[4] Bound, John and Alan B. Krueger, 1991. "The Extent of Measurement Error in Longitudinal Earnings Data: Do Two Wrongs Make a Right?," Journal of Labor Economics, vol. 9(1), pp. 1-24.

[5] Brown, Meta, Christopher J. Flinn and Andrew Schotter, 2011. "Real-Time Search in the Laboratory and the Market," American Economic Review, vol. 101(2), pp. 948-74.

[6] Burdett, Kenneth and Tara Vishwanath, 1988. "Declining Reservation Wages and Learning," Review of Economic Studies, Wiley Blackwell, vol. 55(4), pp. 655-65.

[7] Card, David, Chetty, Raj and Andrea Weber, 2007. "Cash-On-Hand and Competing Models of Intertemporal Behavior: New Evidence from the Labor Market," Quarterly Journal of Economics, vol. 122(4), pp. 1511-1560.

[8] Clark, Andrew E., Ed Diener, Yannis Georgellis and Richard E. Lucas, 2008. "Lags And Leads in Life Satisfaction: a Test of the Baseline Hypothesis," Economic Journal, vol. 118(529), pp. 222-243.

[9] Danforth, John. 1979. "On the Role of Consumption and Decreasing Absolute Risk Aversion in the Theory of Job Search." In Studies in The Economics of Search, ed. Steven A. Lippman and John J. McCall, 109-131. New York: North-Holland.

[10] DellaVigna, Stefano and M. Daniele Paserman, 2005. "Job Search and Impatience," Journal of Labor Economics, vol. 23(3), pp. 527-588.

[11] Devine, Theresa J. and Nicolas M. Kiefer, 1991. Empirical Labor Economics: The Search Approach, Oxford University Press.

[12] Diamond, Peter A., 1971. "A model of price adjustment," Journal of Economic Theory, vol. 3(2), pp. 156-168.

[13] Dohmen, Thomas, Armin Falk, David Huffman, Uwe Sunde, Jürgen Schupp and Gert G. Wagner, 2005. "Individual Risk Attitudes: New Evidence from a Large, Representative, ExperimentallyValidated Survey," IZA Discussion Papers 1730, Institute for the Study of Labor (IZA).

[14] Feldstein, Martin and James Poterba, 1984. "Unemployment insurance and reservation wages," Journal of Public Economics, vol. 23(1-2), pp. 141-167. 
[15] Gruber, Jonathan, 1997. "The Consumption Smoothing Benefits of Unemployment Insurance," American Economic Review, vol. 87(1), pp. 192-205.

[16] Hall, Robert E. and Andreas I. Mueller, 2013. "Wage Dispersion and Search Behavior," mimeo.

[17] Holzer, Harry J., 1986. "Reservation Wages and Their Labor Market Effects for Black and White Male Youth," Journal of Human Resources, vol. 21(2), pp. 157-177.

[18] Hornstein, Andreas, Per Krusell and Giovanni L. Violante, 2011. "Frictional Wage Dispersion in Search Models: A Quantitative Assessment," American Economic Review, vol. 101(7), pp. 2873-98.

[19] Nekoei, Arash and Andrea Weber, 2013. "Does Extending Unemployment Benefits Improve Job Quality?" mimeo, Harvard University, Cambridge, MA.

[20] Kasper, Hirschel, 1967. "The Asking Price of Labor and the Duration of Unemployment," Review of Economics and Statistics, vol. 49, pp. 165-72.

[21] Kroft, Kory and Matthew J. Notowdigdo (2011). "Should Unemployment Insurance Vary With the Unemployment Rate? Theory and Evidence." NBER Working Paper No. 17173.

[22] Kroft, Kory, Fabian Lange and Matthew J. Notowidigdo, 2013. "Duration Dependence and Labor Market Conditions: Theory and Evidence from a Field Experiment," Quarterly Journal of Economics, vol. 128(3), pp. 1123-1167.

[23] Krueger, Alan B. and Andreas I. Mueller, 2011. "Job Search, Emotional Well-Being and Job Finding in a Period of Mass Unemployment: Evidence from High-Frequency Longitudinal Data," Brookings Papers on Economic Activity, vol. 42(1), pp. 1-81.

[24] Krueger, Alan B. and Andreas I. Mueller, 2012. "Time Use, Emotional Well-Being, and Unemployment: Evidence from Longitudinal Data," American Economic Review, vol. 102(3), pp. 594-99.

[25] Landais, Camille, 2013. "Assessing the Welfare Effects of Unemployment Benefits Using the Regression Kink Design." IZA Discussion Paper No. 7589, Institute for the Study of Labor (IZA).

[26] Lusardi, Annamaria, Dandiel J. Schneider and Peter Tufanon, 2011. "Financially Fragile Households: Evidence and Implications," Brookings Papers on Economic Activity, vol. 42(1), pp. 83-150.

[27] Meyer, Bruce D, 1990. "Unemployment Insurance and Unemployment Spells," Econometrica, vol. 58(4), pp. 757-82.

[28] Mortensen, Dale T., 1977. "Unemployment insurance and job search decisions," Industrial and Labor Relations Review, vol. 30(4), pp. 505-517.

[29] Schmieder, Johannes F., Till von Wachter and Stefan Bender, 2012. "The Effects of Extended Unemployment Insurance Over the Business Cycle: Evidence from Regression Discontinuity Estimates Over 20 Years," The Quarterly Journal of Economics, vol. 127(2), pp. 701-752. 
[30] Schmieder, Johannes F., Till von Wachter and Stefan Bender, 2013. "The Effect of Unemployment Insurance Extensions on Reemployment Wages." NBER Working Paper No. 19772.

[31] Shimer, Robert and Iván Werning, 2007. "Reservation Wages and Unemployment Insurance," The Quarterly Journal of Economics, vol. 122(3), pp. 1145-1185. 


\begin{tabular}{|c|c|c|c|c|}
\hline & (1) & $(2)$ & (3) & (4) \\
\hline \multirow[t]{2}{*}{ Log(weekly benefit) } & -0.047 & 0.015 & -0.046 & -0.031 \\
\hline & $(0.059)$ & $(0.067)$ & $(0.060)$ & $(0.060)$ \\
\hline \multirow[t]{2}{*}{ Log(weekly previous wage) } & -0.505 & -0.559 & -0.501 & -0.522 \\
\hline & $(0.047)^{* * *}$ & $(0.053)^{* * *}$ & $(0.048)^{* * *}$ & $(0.046)^{* * *}$ \\
\hline \multirow[t]{2}{*}{ Received severance payment } & & & -0.017 & -0.020 \\
\hline & & & $(0.018)$ & $(0.018)$ \\
\hline \multirow[t]{2}{*}{ Severance payment amount (in \$) / 10,000 } & & & 0.009 & 0.006 \\
\hline & & & $(0.004)^{* *}$ & $(0.005)$ \\
\hline \multirow[t]{2}{*}{ Savings: \$10,000-\$24,999 } & & & & 0.014 \\
\hline & & & & $(0.023)$ \\
\hline \multirow[t]{2}{*}{ Savings: \$25,000-\$49,999 } & & & & 0.044 \\
\hline & & & & $(0.034)$ \\
\hline \multirow[t]{2}{*}{ Savings: $\$ 50,000-\$ 99,999$} & & & & -0.028 \\
\hline & & & & $(0.069)$ \\
\hline \multirow[t]{2}{*}{ Savings: $\$ 100,000$ or more } & & & & 0.115 \\
\hline & & & & $(0.033)^{* * *}$ \\
\hline \multirow[t]{2}{*}{ Access to $\$ 5000$ in case of emergency } & & & & -0.005 \\
\hline & & & & $(0.015)$ \\
\hline \multirow[t]{2}{*}{ Access to at least one credit card } & & & & 0.041 \\
\hline & & & & $(0.020)^{* *}$ \\
\hline \multirow[t]{2}{*}{ Spouse has job } & & & & 0.018 \\
\hline & & & & $(0.026)$ \\
\hline \multirow[t]{2}{*}{ Incentive choice: $\$ 40$} & & & & 0.010 \\
\hline & & & & $(0.018)$ \\
\hline \multirow{2}{*}{$\begin{array}{l}\text { Degree of risk loving } \\
\text { ( } 0=\text { Unwilling to take risk; } 10=\text { Very willing to take risks) }\end{array}$} & & & & 0.011 \\
\hline & & & & $(0.003)^{* * * *}$ \\
\hline \multirow[t]{2}{*}{ County unemployment rate } & -0.003 & -0.003 & -0.001 & -0.001 \\
\hline & $(0.005)$ & $(0.005)$ & $(0.005)$ & $(0.004)$ \\
\hline \multirow{2}{*}{ Unemployment duration (weeks paid) } & -0.002 & -0.002 & -0.002 & -0.002 \\
\hline & $(0.000)^{* * *}$ & $(0.000)^{* * *}$ & $(0.000)^{* * *}$ & $(0.000)^{* * *}$ \\
\hline \multirow[t]{2}{*}{ Years of school } & 0.019 & 0.017 & 0.019 & 0.017 \\
\hline & $(0.005)^{* * *}$ & $(0.005)^{* * *}$ & $(0.005)^{* * *}$ & $(0.005)^{* * *}$ \\
\hline \multirow[t]{2}{*}{ Job tenure on previous job, in years } & -0.003 & -0.003 & -0.004 & -0.004 \\
\hline & $(0.001)^{* *}$ & $(0.001)^{*}$ & $(0.001)^{* * *}$ & $(0.001)^{* * *}$ \\
\hline Experience/10 & 0.110 & 0.133 & 0.109 & 0.114 \\
\hline & $(0.024)^{* * *}$ & $(0.030)^{* * *}$ & $(0.024)^{* * *}$ & $(0.023)^{* * *}$ \\
\hline Experience $^{\wedge} 2 / 100$ & -0.023 & -0.027 & -0.023 & -0.024 \\
\hline & $(0.005)^{* * *}$ & $(0.007)^{* * *}$ & $(0.005)^{* * *}$ & $(0.005)^{* * *}$ \\
\hline Female & -0.083 & -0.079 & -0.083 & -0.086 \\
\hline & $(0.016)^{* * *}$ & $(0.020)^{* * *}$ & $(0.017)^{* * *}$ & $(0.020)^{* * *}$ \\
\hline Married & -0.006 & -0.019 & -0.008 & -0.031 \\
\hline & $(0.020)$ & $(0.021)$ & $(0.020)$ & $(0.026)$ \\
\hline Number of children & -0.002 & -0.007 & -0.002 & 0.000 \\
\hline & $(0.005)$ & $(0.005)$ & $(0.005)$ & $(0.005)$ \\
\hline Black & -0.021 & -0.017 & -0.021 & -0.016 \\
\hline & $(0.033)$ & $(0.035)$ & $(0.034)$ & $(0.037)$ \\
\hline Asian or other & 0.017 & -0.005 & 0.005 & 0.004 \\
\hline & $(0.043)$ & $(0.057)$ & $(0.044)$ & $(0.041)$ \\
\hline Race not available & 0.009 & 0.024 & 0.011 & 0.010 \\
\hline & $(0.032)$ & $(0.031)$ & $(0.032)$ & $(0.030)$ \\
\hline Not hispanic & 0.026 & 0.022 & 0.031 & 0.033 \\
\hline & $(0.026)$ & $(0.029)$ & $(0.026)$ & $(0.025)$ \\
\hline Ethnicity not available & -0.009 & -0.021 & -0.014 & -0.009 \\
\hline & $(0.027)$ & $(0.025)$ & $(0.026)$ & $(0.025)$ \\
\hline Dummies for industry and occupation (2-digit) & $\mathrm{x}$ & $\mathrm{x}$ & $\mathrm{x}$ & $\mathrm{x}$ \\
\hline Dummy for imputed wage above top code & $\mathrm{x}$ & $\mathrm{x}$ & $\mathrm{x}$ & $\mathrm{x}$ \\
\hline Dummies for unit of reported reservation wage & $\mathrm{x}$ & $\mathrm{x}$ & $\mathrm{x}$ & $\mathrm{x}$ \\
\hline $\mathrm{N}$ & 3,841 & 2,797 & 3,687 & 3,530 \\
\hline R-squared & 0.496 & 0.512 & 0.497 & 0.509 \\
\hline
\end{tabular}


Table 2. Reservation wage ratio by duration of unemployment

\begin{tabular}{|c|c|c|c|c|c|c|c|c|}
\hline & $\stackrel{\text { All }}{\text { durations }}$ & $\frac{\text { Less }}{\text { than } 5}$ & $\frac{\underline{5-9}}{\underline{\text { weeks }}}$ & $\frac{10-14}{\underline{\text { weeks }}}$ & $\frac{15-19}{\underline{\text { weeks }}}$ & $\frac{20-24}{\underline{\text { weeks }}}$ & $\frac{25-49}{\underline{\text { weeks }}}$ & $\underline{\underline{50+}} \underline{\underline{\text { weeks }}}$ \\
\hline $\begin{array}{l}\text { Feldstein \& Poterba (1984): } \\
\text { All Job Losers and Leavers }\end{array}$ & 1.07 & 1.11 & 1.09 & 1.04 & 1.06 & 1.04 & 1.02 & 0.99 \\
\hline $\begin{array}{l}\text { Feldstein \& Poterba (1984): } \\
\text { Job Losers }\end{array}$ & 1.03 & 1.06 & 1.05 & 1.03 & 1.06 & 1.00 & 0.99 & 0.97 \\
\hline $\begin{array}{l}\text { Krueger \& Mueller: } \\
\text { Cross-section (1st week) }\end{array}$ & 0.99 & 1.04 & 1.02 & 1.01 & 1.00 & 1.06 & 0.95 & 0.94 \\
\hline $\begin{array}{l}\text { Krueger \& Mueller: } \\
\text { Longitudinal estimate }\end{array}$ & 0.99 & 1.00 & 1.00 & 1.00 & 0.99 & 0.99 & 0.98 & 0.97 \\
\hline $\begin{array}{l}\text { Krueger \& Mueller: } \\
\text { Longitudinal estimate (full- } \\
\text { time workers) }\end{array}$ & 1.00 & 1.03 & 1.02 & 1.01 & 1.01 & 1.00 & 0.98 & 0.94 \\
\hline
\end{tabular}

Note: Survey weights are used. Universe: Unemployed; no job offer yet accepted; age 20-65. Feldstein and Poterba's (1984) estimates are from a sample of 2,228 unemployed from the May 1976 Current Population Survey. 
Table 3a. Regressions of log weekly reservation wage ratio on duration of unemployment, with and without fixed effects

\begin{tabular}{|c|c|c|c|c|}
\hline $\begin{array}{l}\text { Dependent variable: } \\
\text { log(reservation wage ratio) }\end{array}$ & Week 1 & $\begin{array}{l}\frac{\text { Pooled }}{\text { cross- }} \\
\text { section }\end{array}$ & $\underline{\underline{\text { Fixed }}}$ & $\begin{array}{l}\frac{\text { Fixed }}{\text { effects }} \\
\end{array}$ \\
\hline & (1) & (2) & (3) & (4) \\
\hline Unemployment duration, in wks & $\begin{array}{c}-0.00193 \\
(0.00035)^{* * *}\end{array}$ & $\begin{array}{c}-0.00125 \\
(0.00043)^{* * *}\end{array}$ & $\begin{array}{l}-0.00056 \\
(0.00056)\end{array}$ & $\begin{array}{r}-0.00046 \\
(0.00080)\end{array}$ \\
\hline Lapse (before November 8) & & & & $\begin{array}{l}0.01871 \\
(0.01423)\end{array}$ \\
\hline Exhausted UI & & & & $\begin{array}{c}-0.01779 \\
(0.02794)\end{array}$ \\
\hline Weeks of UI left: 1-4 & & & & $\begin{array}{c}-0.00541 \\
(0.01333)\end{array}$ \\
\hline Weeks of UI left: 5-8 & & & & $\begin{array}{l}0.00772 \\
(0.01306)\end{array}$ \\
\hline Weeks of UI left: 9-12 & & & & $\begin{array}{l}0.00115 \\
(0.00884)\end{array}$ \\
\hline After extension of November 8 & & & & $\begin{array}{l}0.00056 \\
(0.00659)\end{array}$ \\
\hline
\end{tabular}

\begin{tabular}{|c|c|c|c|c|c|c|c|c|c|c|}
\hline Controls (see footnote) & $\mathrm{x}$ & $\mathrm{x}$ & & & & & & & & \\
\hline Individual fixed effects & & & $\mathrm{x}$ & $\mathrm{x}$ & $\mathrm{x}$ & $\mathrm{x}$ & $\mathrm{x}$ & $\mathrm{x}$ & $\mathrm{x}$ & $\mathrm{x}$ \\
\hline Reservation wage unit dummies & $\mathrm{x}$ & $\mathrm{x}$ & $\mathrm{x}$ & $\mathrm{x}$ & $\mathrm{x}$ & $\mathrm{x}$ & $\mathrm{x}$ & $\mathrm{x}$ & $\mathrm{x}$ & $\mathrm{x}$ \\
\hline Mean of dependent variable & -0.08 & -0.11 & -0.10 & -0.10 & -0.06 & -0.28 & -0.05 & -0.25 & -0.23 & -0.34 \\
\hline $\mathrm{N}$ & 3,841 & 22,701 & 24,474 & 24,474 & 16,057 & 6,796 & 13,565 & 10,909 & 2,655 & 4,141 \\
\hline R-squared & 0.50 & 0.52 & 0.94 & 0.94 & 0.94 & 0.95 & 0.94 & 0.93 & 0.96 & 0.92 \\
\hline
\end{tabular}

Notes: Survey weights are used. Universe: Unemployed; no job offer yet accepted; age 20-65. The controls in Columns 1-3 are the same as in Column 2 of Table 1. 
Table 3b. Regressions of log weekly reservation wage ratio on duration of unemployment, with and without fixed effects (full-time workers only)

\begin{tabular}{|c|c|c|c|c|c|c|c|c|c|c|}
\hline $\begin{array}{l}\text { Dependent variable: } \\
\text { log(reservation wage ratio) }\end{array}$ & Week 1 & $\frac{\text { Pooled }}{\underline{\text { cross- }}} \frac{\text { section }}{}$ & $\begin{array}{l}\text { Fixed } \\
\text { effects }\end{array}$ & $\begin{array}{l}\underline{\text { Fixed }} \\
\text { effects }\end{array}$ & $\begin{array}{c}\text { Savings } \\
\leq \$ 10,000 \\
\end{array}$ & $\begin{array}{c}\frac{\text { Savings }}{>=} \\
\underline{\$ 10,000}\end{array}$ & Age 20-50 & Age 51-65 & $\begin{array}{l}\frac{\text { Savings }}{>=\$ 10,000} \\
\underline{\text { (age } 20-50)}\end{array}$ & $\begin{array}{c}\frac{\text { Savings }}{>=\$ 10,000} \\
\underline{\text { (age 51-65) }}\end{array}$ \\
\hline & (1) & $(2)$ & (3) & (4) & (5) & (6) & (7) & $(8)$ & (9) & $(10)$ \\
\hline Unemployment duration, in wks & $\begin{array}{c}-0.00157 \\
(0.00036)^{* * *}\end{array}$ & $\begin{array}{c}-0.00126 \\
(0.00047)^{* * *}\end{array}$ & $\begin{array}{l}-0.00137 \\
(0.00060)^{* *}\end{array}$ & $\begin{array}{l}-0.00145 \\
(0.00070)^{* *}\end{array}$ & $\begin{array}{c}-0.00074 \\
(0.00069)\end{array}$ & $\begin{array}{l}-0.00321 \\
(0.00148)^{* *}\end{array}$ & $\begin{array}{c}-0.00053 \\
(0.00082)\end{array}$ & $\begin{array}{c}-0.00271 \\
(0.00084)^{* * *}\end{array}$ & $\begin{array}{c}-0.00193 \\
(0.00224)\end{array}$ & $\begin{array}{l}-0.00404 \\
(0.00194)^{* *}\end{array}$ \\
\hline Lapse (before November 8) & & & & $\begin{array}{l}0.02431 \\
(0.01639)\end{array}$ & & & & & & \\
\hline Exhausted UI & & & & $\begin{array}{c}-0.02030 \\
(0.03886)\end{array}$ & & & & & & \\
\hline Weeks of UI left: $1-4$ & & & & $\begin{array}{l}0.00433 \\
(0.01486)\end{array}$ & & & & & & \\
\hline Weeks of UI left: 5-8 & & & & $\begin{array}{l}0.01328 \\
(0.01472)\end{array}$ & & & & & & \\
\hline Weeks of UI left: 9-12 & & & & $\begin{array}{l}0.00646 \\
(0.00968)\end{array}$ & & & & & & \\
\hline After extension of November 8 & & & & $\begin{array}{l}0.00202 \\
(0.00694)\end{array}$ & & & & & & \\
\hline Controls (see footnote) & $\mathrm{x}$ & $\mathrm{x}$ & & & & & & & & \\
\hline Individual fixed effects & & & $\mathrm{x}$ & $\mathrm{x}$ & $\mathrm{x}$ & $\mathrm{x}$ & $\mathrm{x}$ & $\mathrm{x}$ & $\mathrm{x}$ & $\mathrm{x}$ \\
\hline Reservation wage unit dummies & $\mathrm{x}$ & $\mathrm{x}$ & $\mathrm{x}$ & $\mathrm{x}$ & $\mathrm{x}$ & $\mathrm{x}$ & $\mathrm{x}$ & $\mathrm{x}$ & $\mathrm{x}$ & $\mathrm{x}$ \\
\hline Mean of dependent variable & -0.07 & -0.11 & -0.10 & -0.10 & -0.05 & -0.29 & -0.04 & -0.25 & -0.25 & -0.34 \\
\hline $\mathrm{N}$ & 3,065 & 17,924 & 19,284 & 19,284 & 12,700 & 5,329 & 10,577 & 8,707 & 2,129 & 3,200 \\
\hline R-squared & 0.55 & 0.57 & 0.95 & 0.95 & 0.95 & 0.95 & 0.95 & 0.94 & 0.96 & 0.92 \\
\hline
\end{tabular}

Robust standard errors in parentheses (clustered at individual level); ${ }^{*} \mathrm{p}<0.1,{ }^{* *} \mathrm{p}<0.05,{ }^{* * *} \mathrm{p}<0.01$.

Notes: Survey weights are used. Universe: Unemployed; no job offer yet accepted; age 20-65. The controls in Columns 1-3 are the same as in Column 2 of Table 1. 
Table 4. Regressions of reservation commuting distance on duration of unemployment, with and without fixed effects

\begin{tabular}{|c|c|c|c|c|}
\hline $\begin{array}{l}\text { Dependent variable: Distance willing to commute, in } \\
\text { min per day (for job paying the reservation wage) }\end{array}$ & $\underline{\text { Week } 1}$ & $\begin{array}{l}\frac{\text { Pooled }}{\text { cross- }} \\
\text { section }\end{array}$ & $\begin{array}{l}\text { Fixed } \\
\text { effects }\end{array}$ & $\begin{array}{l}\underline{\text { Fixed }} \\
\text { effects }\end{array}$ \\
\hline Unemployment duration, in weeks & $\begin{array}{c}-0.022 \\
(0.029)\end{array}$ & $\begin{array}{l}0.008 \\
(0.025)\end{array}$ & $\begin{array}{c}0.089 \\
(0.039)^{* *}\end{array}$ & $\begin{array}{c}0.111 \\
(0.049)^{* *}\end{array}$ \\
\hline Lapse (before November 8) & & & & $\begin{array}{l}1.166 \\
(1.642)\end{array}$ \\
\hline Exhausted UI & & & & $\begin{array}{l}-1.216 \\
(1.851)\end{array}$ \\
\hline Weeks of UI left: 1-4 & & & & $\begin{array}{l}-0.796 \\
(1.246)\end{array}$ \\
\hline Weeks of UI left: 5-8 & & & & $\begin{array}{l}0.046 \\
(1.158)\end{array}$ \\
\hline Weeks of UI left: 9-12 & & & & $\begin{array}{l}-1.512 \\
(0.898)^{*}\end{array}$ \\
\hline After extension of November 8 & & & & $\begin{array}{r}-0.012 \\
(0.436)\end{array}$ \\
\hline $\begin{array}{l}\text { Controls (as in Column } 1 \text { of Table } 1 \text { ) } \\
\text { Individual fixed effects }\end{array}$ & $\mathrm{x}$ & $\mathrm{x}$ & $\mathrm{x}$ & $\mathrm{x}$ \\
\hline Mean of dependent variable & 41.5 & 40.7 & 40.8 & 40.8 \\
\hline $\mathrm{N}$ & 4,068 & 24,304 & 26,995 & 26,995 \\
\hline R-squared & 0.21 & 0.27 & 0.90 & 0.90 \\
\hline
\end{tabular}

Notes: Survey weights are used. Universe: Unemployed; no job offer yet accepted; age 20-65. 
Table 5. Regressions of the occupational reservation wage on duration of unemployment, with and without fixed effects

\begin{tabular}{|c|c|c|c|c|}
\hline $\begin{array}{l}\text { Dependent variable: } \\
\text { log(occupational reservation wage) }\end{array}$ & Week 1 & $\begin{array}{c}\frac{\text { Pooled }}{\text { cross- }} \\
\underline{\text { section }}\end{array}$ & $\begin{array}{l}\text { Fixed } \\
\text { effects }\end{array}$ & $\begin{array}{l}\text { Fixed } \\
\text { effects }\end{array}$ \\
\hline Unemployment duration, in weeks & $\begin{array}{c}-0.00072 \\
(0.00021)^{* * *}\end{array}$ & $\begin{array}{c}-0.00011 \\
(0.00022)\end{array}$ & $\begin{array}{l}-0.00123 \\
(0.00057)^{* *}\end{array}$ & $\begin{array}{r}-0.00141 \\
(0.00091)\end{array}$ \\
\hline Lapse (before November 8) & & & & $\begin{array}{r}-0.00622 \\
(0.01190)\end{array}$ \\
\hline Exhausted UI & & & & $\begin{array}{l}0.02414 \\
(0.01912)\end{array}$ \\
\hline Weeks of UI left: 1-4 & & & & $\begin{array}{l}0.01454 \\
(0.01957)\end{array}$ \\
\hline Weeks of UI left: 5-8 & & & & $\begin{array}{l}0.00438 \\
(0.01284)\end{array}$ \\
\hline Weeks of UI left: 9-12 & & & & $\begin{array}{l}0.00734 \\
(0.01124)\end{array}$ \\
\hline After extension of November 8 & & & & $\begin{array}{r}-0.00123 \\
(0.00578) \\
\end{array}$ \\
\hline Controls (as in Column 1 of Table 1 ) & $\mathrm{x}$ & $\mathrm{x}$ & & \\
\hline Individual fixed effects & & & $\mathrm{x}$ & $\mathrm{x}$ \\
\hline Dummies for unit of reported reservation wage & $\mathrm{x}$ & $\mathrm{x}$ & $\mathrm{x}$ & $\mathrm{x}$ \\
\hline Mean of dependent variable & -0.62 & -0.63 & -0.63 & -0.63 \\
\hline $\mathrm{N}$ & 3,715 & 21,856 & 24,272 & 24,272 \\
\hline R-squared & 0.45 & 0.42 & 0.83 & 0.83 \\
\hline
\end{tabular}

Notes: Survey weights are used. Universe: Unemployed; no job offer yet accepted; age 20-65. 
Table 6. Fixed-effect regressions of a dummy for access to $\$ 5,000$ on duration of unemployment

Access to \$5,000 through:

\begin{tabular}{|c|c|c|c|c|c|c|}
\hline Dependent variable: & $\frac{\text { Access to }}{\underline{\$ 5,000}}$ & $\underline{\text { Savings }}$ & $\begin{array}{l}\text { Selling } \\
\underline{\text { stocks }}\end{array}$ & $\frac{\frac{\text { Borrowing }}{\text { from friends }}}{\underline{\text { or family }}}$ & $\frac{\frac{\text { Borrowing }}{\text { (bank, credit }}}{\frac{\text { card, home }}{\text { equity loan) }}}$ & Other \\
\hline Unemployment duration, in wks & $\begin{array}{c}-0.00188 \\
(0.00074)^{* *}\end{array}$ & $\begin{array}{l}-0.00107 \\
(0.00051)^{* *}\end{array}$ & $\begin{array}{c}-0.00031 \\
(0.00015)^{* *}\end{array}$ & $\begin{array}{c}-0.00029 \\
(0.00062)\end{array}$ & $\begin{array}{l}0.00007 \\
(0.00037)\end{array}$ & $\begin{array}{c}-0.00026 \\
(0.00028)\end{array}$ \\
\hline Mean of dependent variable & 0.294 & 0.169 & 0.015 & 0.049 & 0.044 & 0.015 \\
\hline $\mathrm{N}$ & 27,080 & 27,080 & 27,080 & 27,080 & 27,080 & 27,080 \\
\hline R-squared & 0.94 & 0.93 & 0.82 & 0.83 & 0.83 & 0.80 \\
\hline
\end{tabular}

Notes: Survey weights are used. Universe: Unemployed; no job offer yet accepted; age 20-65. 
Table 7a. Hourly offered wage below and above hourly reservation wage Hourly offered wage $<$ hourly reservation wage

Hourly offered wage $>=$ hourly reservation wage

\begin{tabular}{lcc}
\hline Accepted & $50.5 \%$ & $74.1 \%$ \\
Not accepted & $23.6 \%$ & $10.3 \%$ \\
Undecided & $25.9 \%$ & $15.7 \%$ \\
\hline $\mathrm{N}$ & 566 & 587 \\
\hline
\end{tabular}

Table 7b. Hourly offered wage below and above hourly reservation wage (full time offers only)

Hourly offered wage <

hourly reservation wage
Hourly offered wage $>=$ hourly reservation wage

\begin{tabular}{lcc}
\hline Accepted & $44.4 \%$ & $73.8 \%$ \\
Not accepted & $24.2 \%$ & $11.4 \%$ \\
Undecided & $31.4 \%$ & $14.8 \%$ \\
\hline $\mathrm{N}$ & 361 & 417 \\
\hline
\end{tabular}


Table 8. Reasons for not accepting offer, by wage offer below and above reservation wage

Reason for not accepting offer

Inadequate pay/benefits

Unsuitable working conditions

Would not make use of my experience or skills

Had insufficient experience or skills

Insufficient hours/too many hours

Changed plans

Transportation problem

Better offer

Other

$\mathrm{N}$
Hourly offered wage < hourly reservation wage

Hourly offered wage $>=$ hourly reservation wage

$1 \%$

$28 \%$

$4 \%$

$4 \%$

$1 \%$

$1 \%$

$19 \%$

$10 \%$

$31 \%$

42

$121 \quad 42 \quad 163$

All

$30 \%$

$9 \%$

$11 \%$

$2 \%$

$6 \%$

$3 \%$

$14 \%$

$5 \%$

$21 \%$ 
Table 9. Marginal effects from Probit model regressions of accepting a job offer

Hourly offered wage >= Hourly reservation wage (lagged)

Hourly offered wage $>=$ Hourly reservation wage (lagged)

* Parttime job offer

Hourly offered wage $>=$ Hourly previous wage

Hourly offered wage $>=$ Hourly previous wage

* Parttime job offer

Parttime job offer

Log(lagged hourly reservation wage)

Log(hourly offered wage)

Log(hourly previous wage)

Savings $<\$ 10,000$

Unemployment duration: 7-12 months

Unemployment duration: 13-18 months

Unemployment duration: 19 months or more
(1)

0.212
$(0.098)^{* *}$

$-0.215$

$(0.127)^{*}$$$
(0.0
$$

(3)

(0.c

(4)

0.196
$(0.061)^{* * *}$

(5)

0.218

$(0.091)^{* *}$

(6)

0.217

0.217
$(0.089)^{* *}$

$-0.222 \quad-0.244$

$(0.123)^{*} \quad(0.123)^{* *}$

$\begin{array}{ll}0.152 & 0.106 \\ (0.101) & (0.070)\end{array}$

$-0.055$

(0.126)

$\begin{array}{lll}0.127 & 0.210 & 0.152\end{array}$

$(0.079)^{*}$

0.212

$(0.077)^{* * *}$

0.194

$(0.076)^{* *}$

$-0.278 \quad-0.109$

$(0.101)^{* * *}$

(0.122)

0.367

$(0.084)^{* * *}$

0.216

$(0.108)^{* *}$

0.185

$(0.091)^{* *}$

$-0.029$

(0.098)

$-0.109 \quad-0.136$

(0.126) (0.146)

0.227

$(0.107)^{* *}$

0.194

(0.112)*

$-0.039$

(0.084)

$0.015 \quad 0.001$

$(0.089) \quad(0.085)$

$0.078 \quad 0.071$

$(0.082) \quad(0.080)$

$0.015 \quad 0.028$

(0.079) (0.078)

$-0.063 \quad-0.011$

(0.148)

\begin{tabular}{lllllrr}
\hline Demographic controls & & & & \\
\hline Mean of dependent variable & 0.614 & 0.614 & 0.614 & 0.614 & 0.614 & 0.611 \\
\hline N & 1,153 & 1,153 & 1,153 & 1,153 & 1,153 & 1,150 \\
Pseudo R-squared & 0.054 & 0.071 & 0.051 & 0.052 & 0.076 & 0.120 \\
\hline
\end{tabular}

Robust standard errors in parentheses (clustered at individual level); * $\mathrm{p}<0.1$, ** $\mathrm{p}<0.05$, ${ }^{* * *} \mathrm{p}<0.01$.

Notes: Survey weights are used. Sample: Respondents; age 20-65. The regression in Column 6 includes additional controls for age, education, gender, marital status, race and ethnicity (as in Table 10). 
Table 10. Determinants of the potential bias in the reported reservation wage

\section{Dependent variable:}

\section{Sample:}

Unemployment duration: 7-12 months

Unemployment duration: 13-18 months

Unemployment duration: 19 months or more

Weeks since reservation wage reported

Part-time job offer

Incentive choice: $\$ 40$

Degree of risk loving

( $0=$ Unwilling to take risk; $10=$ Very willing to take risks)

Initial savings less than $\$ 10,000$

Age / 10

Age $^{\wedge} 2 / 100$

Some college education

College degree

Some graduate education

Graduate degree

Female

Married

Female*married

Black

Asian or other race

Race not available

Hispanic

Ethnicity not available
Probability of accepting job offer

Offers below the reservation wage

0.085
$(0.112)$
-0.002
$(0.110)$
0.234
$(0.100)^{* *}$
-0.051
$(0.027)^{*}$
0.230
$(0.087)^{* * *}$

(0.087)

0.033

(0.106)

$-0.033$

(0.117)

0.242

$(0.106)^{* *}$

$-0.057$

$(0.027) * *$

0.184

$(0.085)^{* *}$

$-0.076$

(0.083)

$-0.073$

$(0.019)^{* * *}$

0.029

(0.109)

0.248

(0.304)

$-0.034$

(0.035)

$-0.017$

(0.120)

0.157

(0.134)

$-0.014$

(0.171)

0.283

$(0.140) * *$

0.117

(0.131)

$-0.048$

(0.149)

$-0.260$

(0.176)

$-0.146$

(0.104)

$-0.239$

(0.210)

0.055

(0.170)

$-0.059$

(0.141)

0.349

$(0.139) * *$
0.094

(0.286)

$-0.016$

(0.033)

$-0.023$

(0.116)

0.191

(0.124)

0.096

(0.150)

0.314

$(0.142)^{* *}$

0.071

(0.121)

0.012

(0.140)

$-0.288$

$(0.167) *$

$-0.080$

(0.102)

$-0.262$

(0.221)

0.144

(0.158)

$-0.090$

(0.131)

0.298

$(0.153)^{*}$
$-0.086$

(0.167)

0.009

(0.019)

0.061

(0.056)

$-0.000$

(0.060)

$-0.093$

(0.077)

0.146

$(0.061) * *$

0.002

(0.071)

0.017

(0.077)

$-0.041$

(0.084)

$-0.032$

(0.057)

0.089

(0.094)

0.014

(0.090)

$-0.081$

(0.077)

0.091

(0.117)
0.007

(0.055)

0.028

(0.048)

$-0.057$

(0.056)

0.027

$(0.008) * * *$

$-0.078$

$(0.044)^{*}$

0.030

(0.041)

$-0.001$

(0.008)

0.123

$(0.057) * *$

$-0.111$

(0.160)

0.014

(0.019)

0.060

(0.055)

0.000

(0.058)

$-0.067$

(0.074)

0.145

$(0.060) * *$

0.002

(0.069)

0.016

(0.076)

$-0.021$

(0.080)

$-0.053$

(0.056)

0.082

(0.089)

0.014

(0.093)

$-0.110$

(0.074)

0.087

(0.119)

\begin{tabular}{|c|c|c|c|c|}
\hline Mean of dependent variable & 0.505 & 0.507 & -0.021 & -0.021 \\
\hline $\mathrm{N}$ & 566 & 564 & 745 & 743 \\
\hline (Pseudo) R-squared & 0.121 & 0.176 & 0.125 & 0.145 \\
\hline
\end{tabular}

Robust standard errors in parentheses (clustered at the individual level); ${ }^{*} \mathrm{p}<0.1,{ }^{* *} \mathrm{p}<0.05,{ }^{* * *} \mathrm{p}<0.01$. 
Table 11. Estimates of the responsiveness of the reservation wage to the level of UI benefits

Source Sample

(1) Cross-sectional regression

Job losers not on layoff
Estimate based on results in

Feldstein and

Poterba (1984)
Welfare gain from a $\$ 1$ increase in $b$
(2) Cross-sectional regression

(3) Cross-sectional regression

(4) Decline of reservation wage over spell of unemployment

(5) Decline of reservation wage over spell of unemployment

(6) Decline of reservation wage over spell of unemployment

(7)

Decline of reservation wage over spell of unemployment
UI recipients

UI recipients $\mathrm{w} /$ savings $<\$ 10,000$

UI recipients

UI recipients $\mathrm{w} /$ savings $<\$ 10,000$

UI recipients (fulltime workers)

UI recipients (fulltime workers) w/ savings $<\$ 10,000$
Estimate of $d(R) / d(b)$

\begin{tabular}{|c|c|c|c|}
\hline $\begin{array}{c}\text { Column } 2 \text { of } \\
\text { Table } 1\end{array}$ & -0.08 & {$[-0.29,0.12]$} & $-\$ 0.32$ \\
\hline
\end{tabular}

\section{Column 3 of} Table 1

$0.03 \quad[-0.20,0.25]$

$-\$ 0.19 \quad[-\$ 0.46, \$ 0.09]$

Column 3 of Table 3a

$0.09 \quad[-0.09,0.26]$

$-\$ 0.11$

[-\$0.33, \$0.09]
Column 5 of Table 3a

$-0.02 \quad[-0.26,0.18]$

$-\$ 0.25$

$[-\$ 0.53, \$ 0.00]$

Column 3 of Table 3b

$0.22 \quad[0.03,0.39]$

$\$ 0.05$

$[-\$ 0.18, \$ 0.25]$

Column 5 of Table 3b

\footnotetext{
Notes: The estimates in rows 2 and 3 are obtained by multiplying the elasticity from regression Table 1 times the average reservation wage and dividing by the average weekly benefit. The estimates in rows 4-7 are obtained by predicting the decline of the reservation wage from the coefficient estimates on unemployment duration in Tables 3a and 3b over the 99 weeks to UI exhaustion and dividing the predicted value by the change from the average replacement rate to a replacement rate of zero. The welfare gain for a $\$ 1$ increase in b is measured in consumption for all future dates, as on p. 1162 in Shimer and Werning (2007). The numbers in square brackets indicate the 95\% confidence interval.
} 
Appendix Table A1. Wage regressions: Hourly reservation wage, offered wage and previous wage

\begin{tabular}{|c|c|c|c|c|c|}
\hline 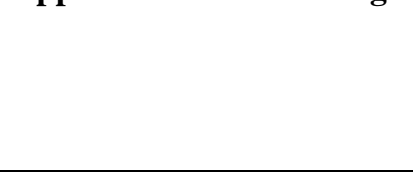 & $\begin{array}{l}\text { Sample: } f i \\
\text { Log(hourly } \\
\text { reservation } \\
\text { wage) }\end{array}$ & $\begin{array}{l}\text { Lek of survey } \\
\text { Log(hourly } \\
\text { previous wage) }\end{array}$ & $\begin{array}{c}\text { Log(hourly } \\
\text { reservation } \\
\text { wage) }\end{array}$ & $\begin{array}{c}\text { Log(hourly } \\
\text { offered wage) }\end{array}$ & $\begin{array}{l}\text { fffers } \\
\text { Log(hourly } \\
\text { previous wage) }\end{array}$ \\
\hline \multirow[t]{2}{*}{ Years of school } & 0.093 & 0.098 & 0.076 & 0.072 & 0.080 \\
\hline & $(0.004)^{* * *}$ & $(0.006) * * *$ & $(0.013)^{* * *}$ & $(0.013)^{* * *}$ & $(0.026)^{* * *}$ \\
\hline \multirow[t]{2}{*}{ Experience/10 } & 0.258 & 0.296 & 0.182 & 0.166 & 0.272 \\
\hline & $(0.028) * * *$ & $(0.036) * * *$ & $(0.069)^{* * *}$ & $(0.071)^{* *}$ & $(0.093)^{* * *}$ \\
\hline \multirow[t]{2}{*}{ Experience $^{\wedge} 2 / 100$} & -0.039 & -0.038 & -0.026 & -0.027 & -0.042 \\
\hline & $(0.007)^{* * *}$ & $(0.008) * * *$ & $(0.017)$ & $(0.018)$ & $(0.022)^{*}$ \\
\hline \multirow[t]{2}{*}{ Female } & -0.122 & -0.111 & -0.148 & -0.160 & -0.190 \\
\hline & $(0.018)^{* * *}$ & $(0.024) * * *$ & $(0.049)^{* * *}$ & $(0.048)^{* * *}$ & $(0.069)^{* * *}$ \\
\hline \multirow[t]{2}{*}{ Married } & 0.091 & 0.117 & 0.131 & 0.081 & 0.130 \\
\hline & $(0.021)^{* * *}$ & $(0.027) * * *$ & $(0.054)^{* *}$ & $(0.051)$ & $(0.069) *$ \\
\hline \multirow[t]{2}{*}{ Black } & -0.193 & -0.173 & -0.159 & -0.292 & -0.211 \\
\hline & $(0.022) * * *$ & $(0.033) * * *$ & $(0.058)^{* * *}$ & $(0.054)^{* * *}$ & $(0.095) * *$ \\
\hline \multirow[t]{2}{*}{ Asian or other } & 0.016 & 0.005 & 0.151 & 0.133 & 0.155 \\
\hline & $(0.058)$ & $(0.065)$ & $(0.122)$ & $(0.128)$ & $(0.171)$ \\
\hline \multirow[t]{2}{*}{ Race not available } & -0.095 & -0.114 & 0.039 & 0.056 & 0.088 \\
\hline & $(0.034)^{* * *}$ & $(0.045)^{* *}$ & $(0.102)$ & $(0.084)$ & $(0.137)$ \\
\hline \multirow[t]{2}{*}{ Not hispanic } & 0.055 & 0.004 & 0.181 & 0.321 & 0.273 \\
\hline & $(0.031)^{*}$ & $(0.040)$ & $(0.091)^{* *}$ & $(0.078)^{* * *}$ & $(0.165)^{*}$ \\
\hline \multirow[t]{2}{*}{ Ethnicity not available } & 0.066 & 0.087 & -0.002 & 0.245 & -0.054 \\
\hline & $(0.038)^{*}$ & $(0.049)^{*}$ & $(0.103)$ & $(0.085)^{* * *}$ & $(0.128)$ \\
\hline \multirow[t]{2}{*}{ Constant } & 1.272 & 1.169 & 1.472 & 1.406 & 1.281 \\
\hline & $(0.068) * * *$ & $(0.090) * * *$ & $(0.202)^{* * *}$ & $(0.186)^{* * *}$ & $(0.340)^{* * *}$ \\
\hline Mean of dependent variable & 2.825 & 2.866 & 2.841 & 2.731 & 2.827 \\
\hline $\mathrm{N}$ & 4,133 & 4,133 & 1,216 & 1,216 & 1,216 \\
\hline R-squared & 0.386 & 0.315 & 0.321 & 0.310 & 0.272 \\
\hline
\end{tabular}

Robust standard errors in parentheses (clustered at the individual level); * $\mathrm{p}<0.1,{ }^{* *} \mathrm{p}<0.05$, *** $\mathrm{p}<0.01$.

Notes: Survey weights are used. Sample for columns 1-3: Interviews with job offers; age 20-65. Sample for columns 4-5: Unemployed; no job offer yet accepted; age 20-65. 
Figure 1: The Reservation Wage over the Spell of Unemployment in the Model

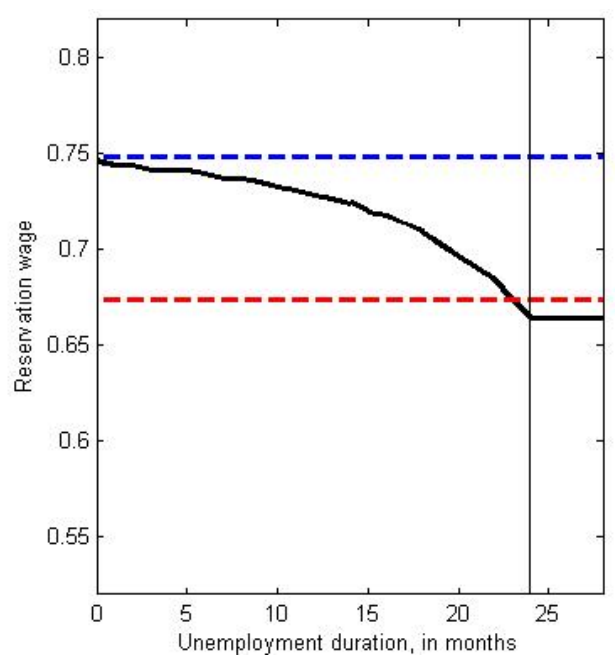

(a)

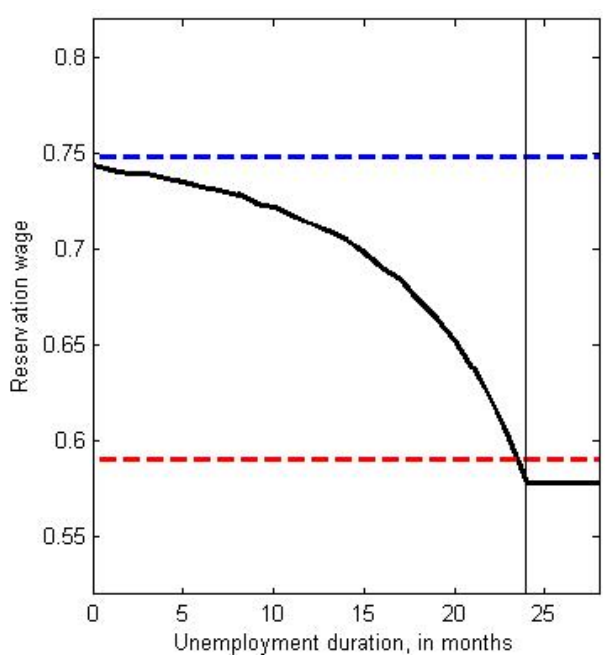

(b)

Notes: The figures show the decline of the reservation wage over the spell of unemployment in the calibrated version of the model described in Section 2. The calibration underlying the figure in Panel (a) assumes that consumption after UI benefit exhaustion drops by 16.7 percent compared to consumption before UI exhaustion, whereas the calibration underlying the figure in Panel (b) assumes that the drop is 33.3 percent. The blue dashed line shows the reservation wage path in an environment where unemployment benefits have unlimited duration, whereas the red dashed line shows the reservation wage in an environment with no unemployment insurance. 
Figure 2. Comparison of Sample Frame and Respondent Sample

\section{A. Kernel Density of The Previous Weekly Wage}

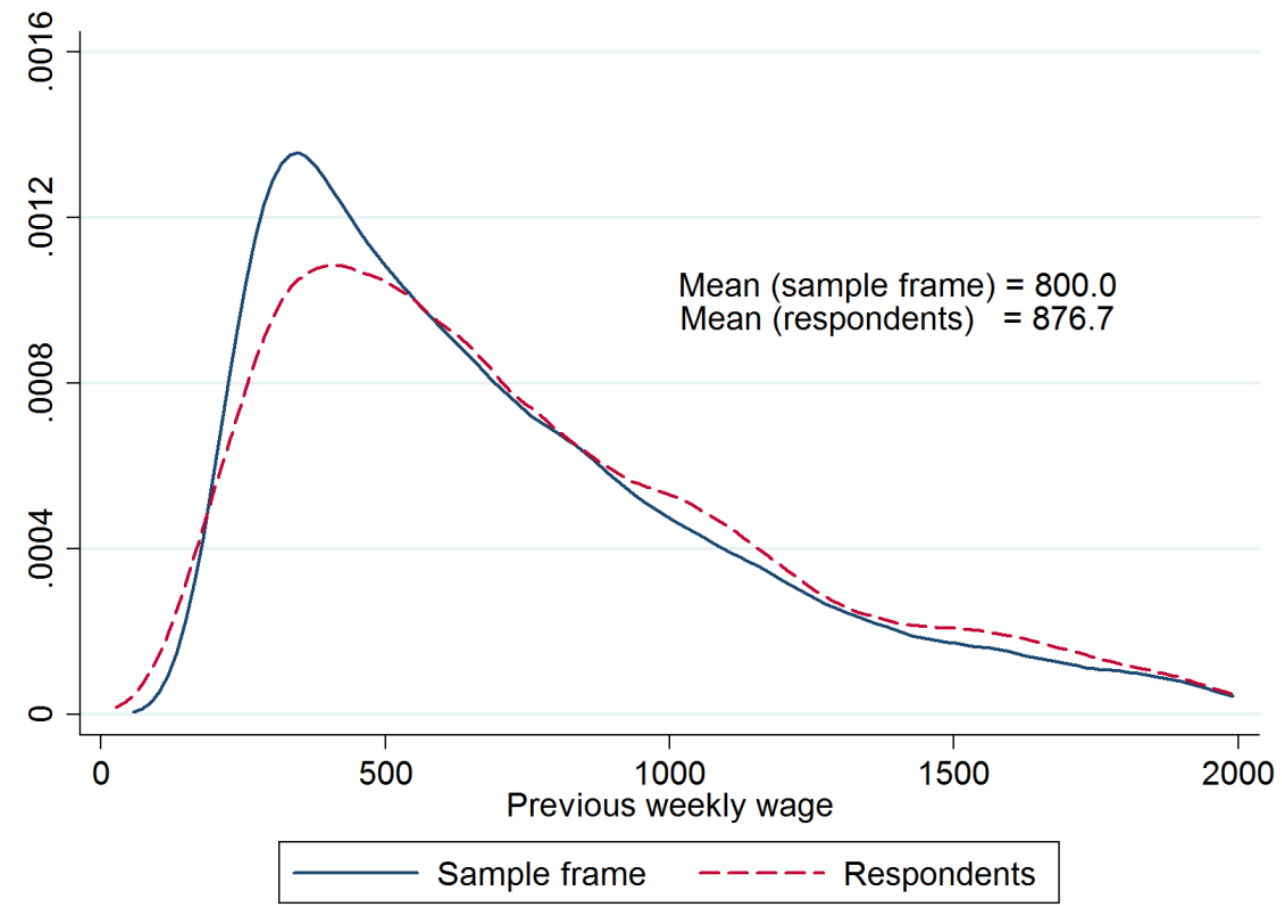

B. Kernel Density of The Ratio of the Weekly Wage in 2010 to the Previous Weekly Wage (Conditional on Positive Earnings in 2010 in NJ)

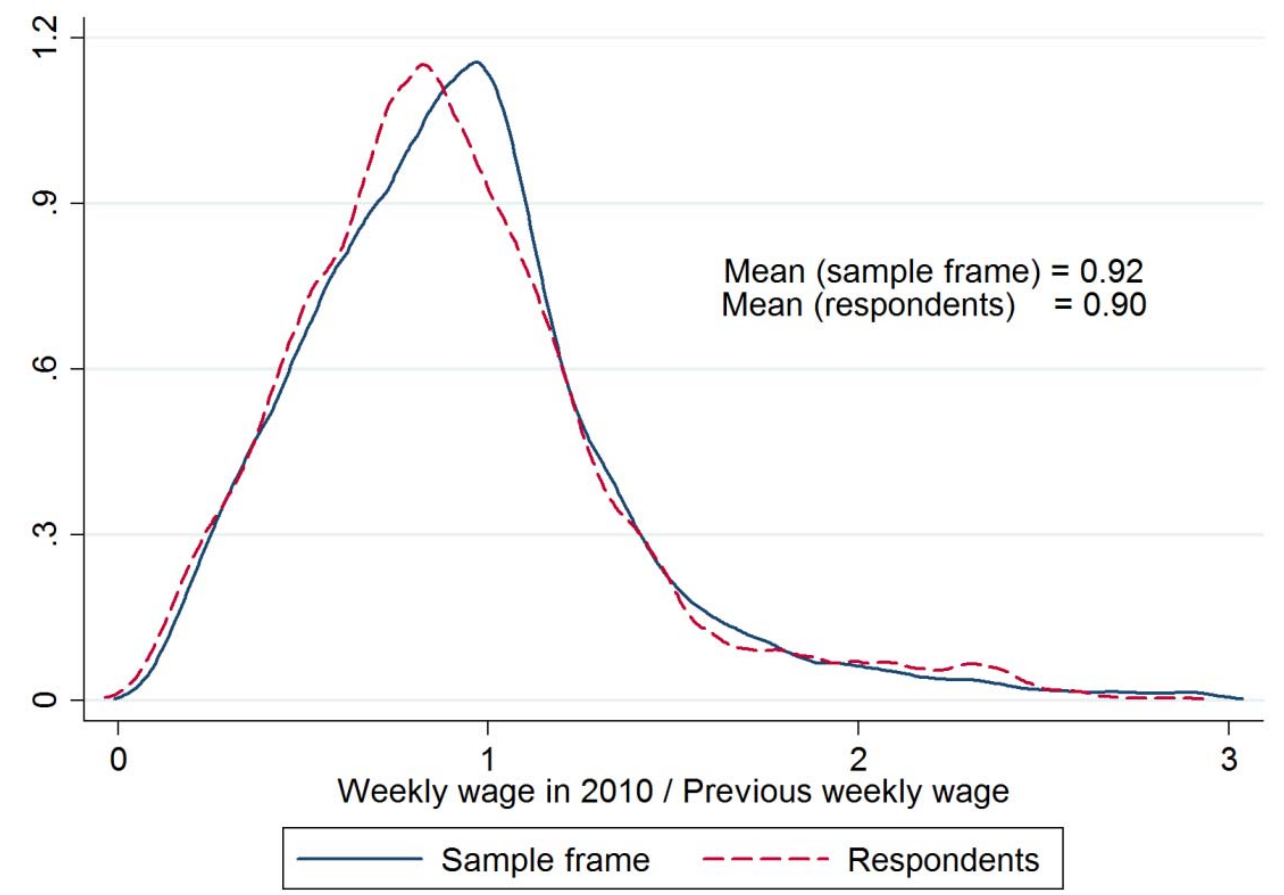

Notes: Both the weekly wage in 2010 and the previous wage are from administrative data. The previous weekly wage is computed from earnings in the base year, which are used to compute the unemployment benefits, whereas the weekly wage in 2010 is computed from NJ wage records (and thus earnings from other states are omitted). Weights are used to adjust for sampling probability and non-response. 
Figure 3. Kernel Density of the Ratio of the Reservation Wage to the Previous Wage

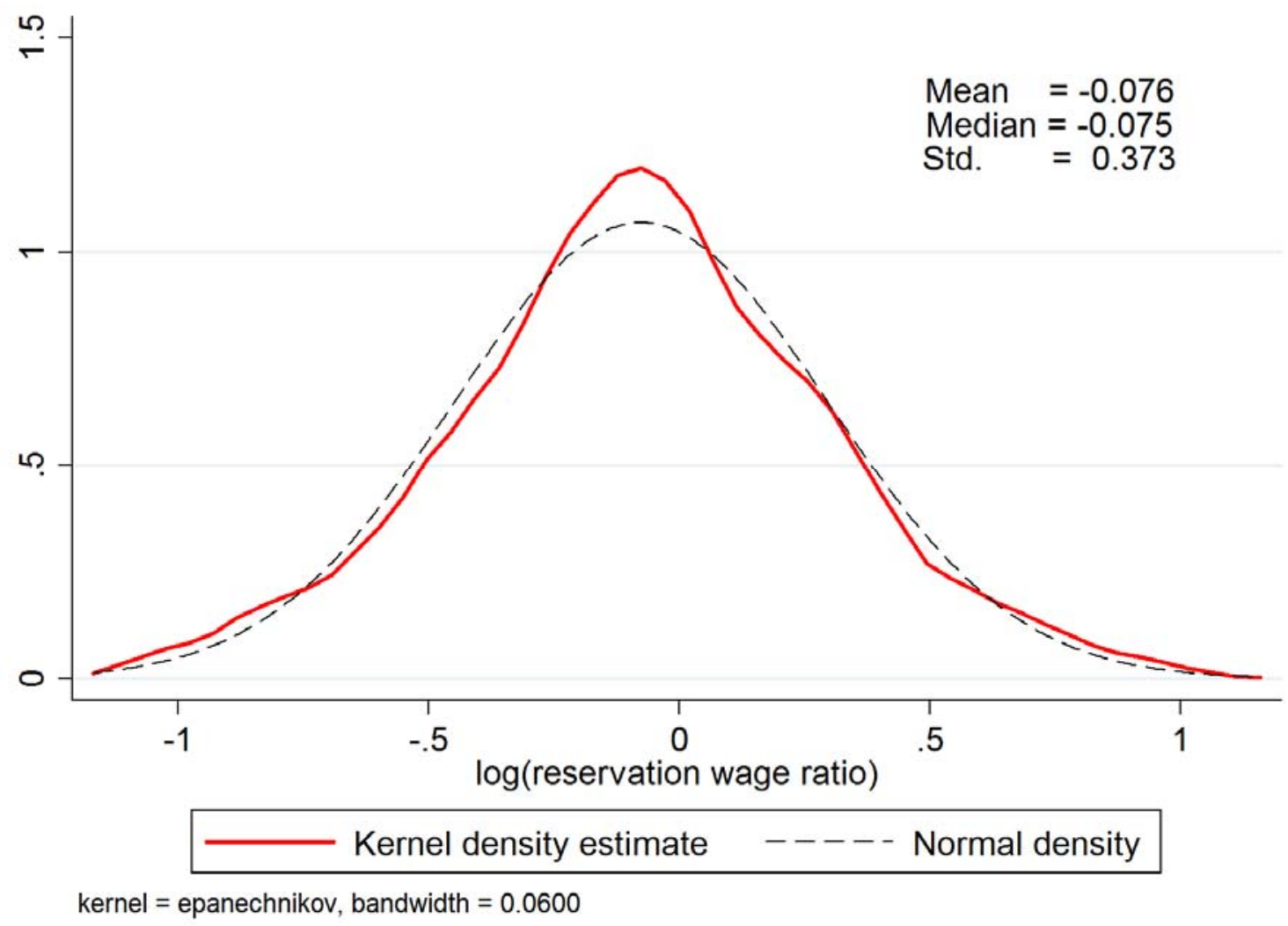


Figure 4a: Average Ratio of Reservation Wage to Previous Wage, by Duration

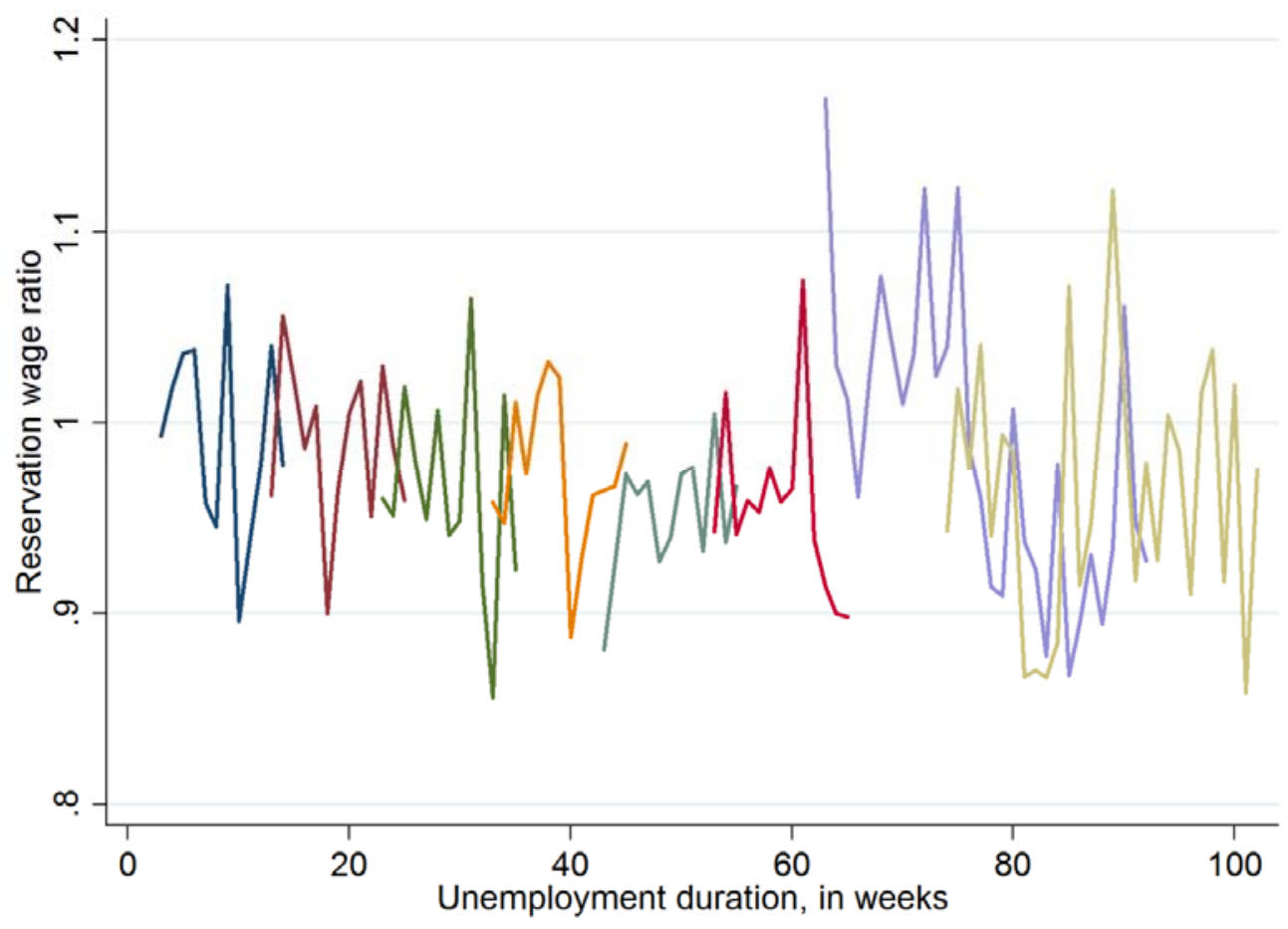

Figure 4b: Average Ratio of Reservation Wage to Previous Wage, by Duration (removing individual fixed effects)

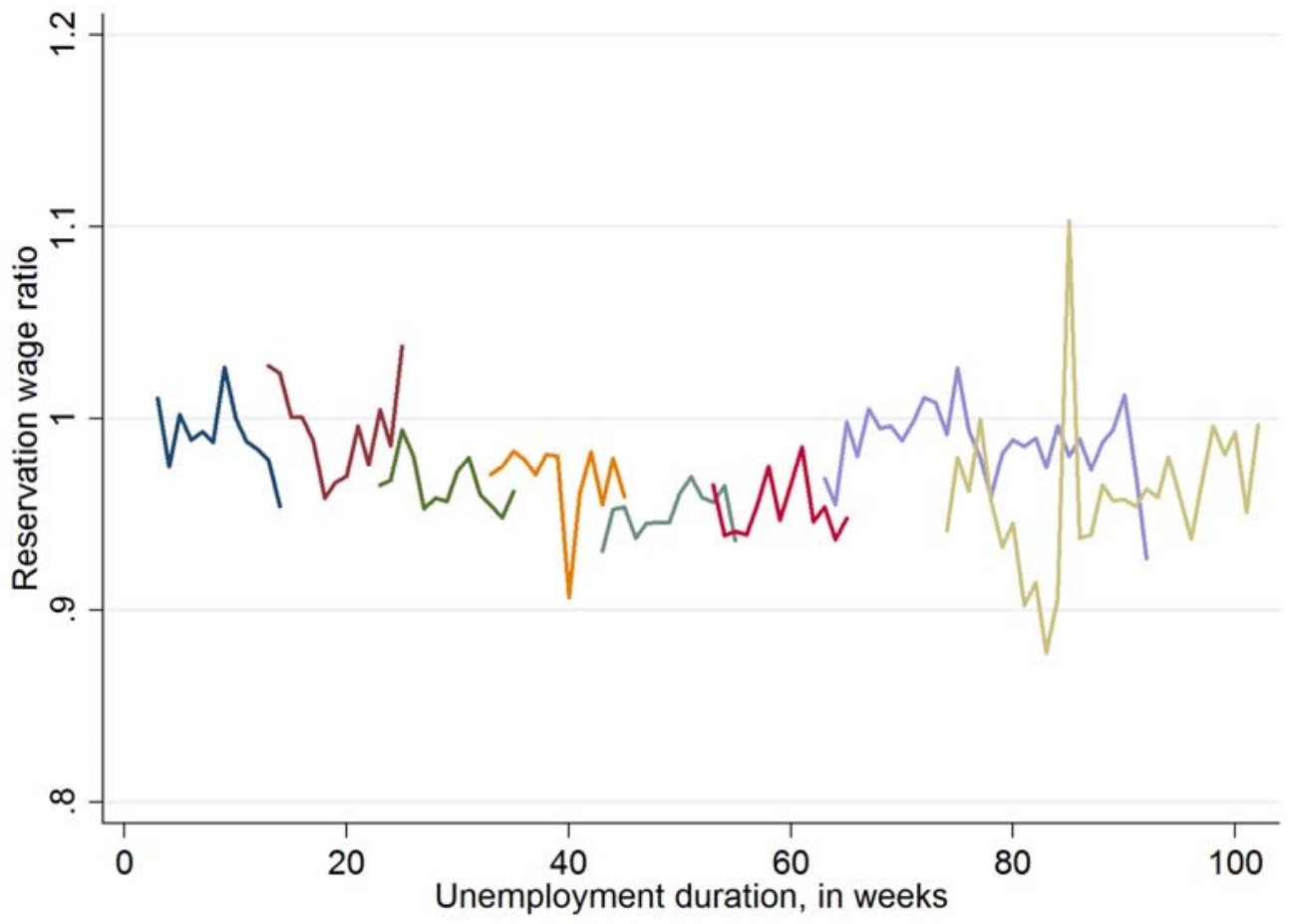

Notes: To remove individual fixed effects, we estimated a regression of the reservation wage ratio on dummies indicating duration of unemployment and individual fixed effects, and then plotted the estimated duration dummies normalized by the average fixed effect of each cohort. 
Figure 5: Average Ratio of Reservation Wage to Previous Wage, before and after UI Exhaustion (removing individual fixed effects)

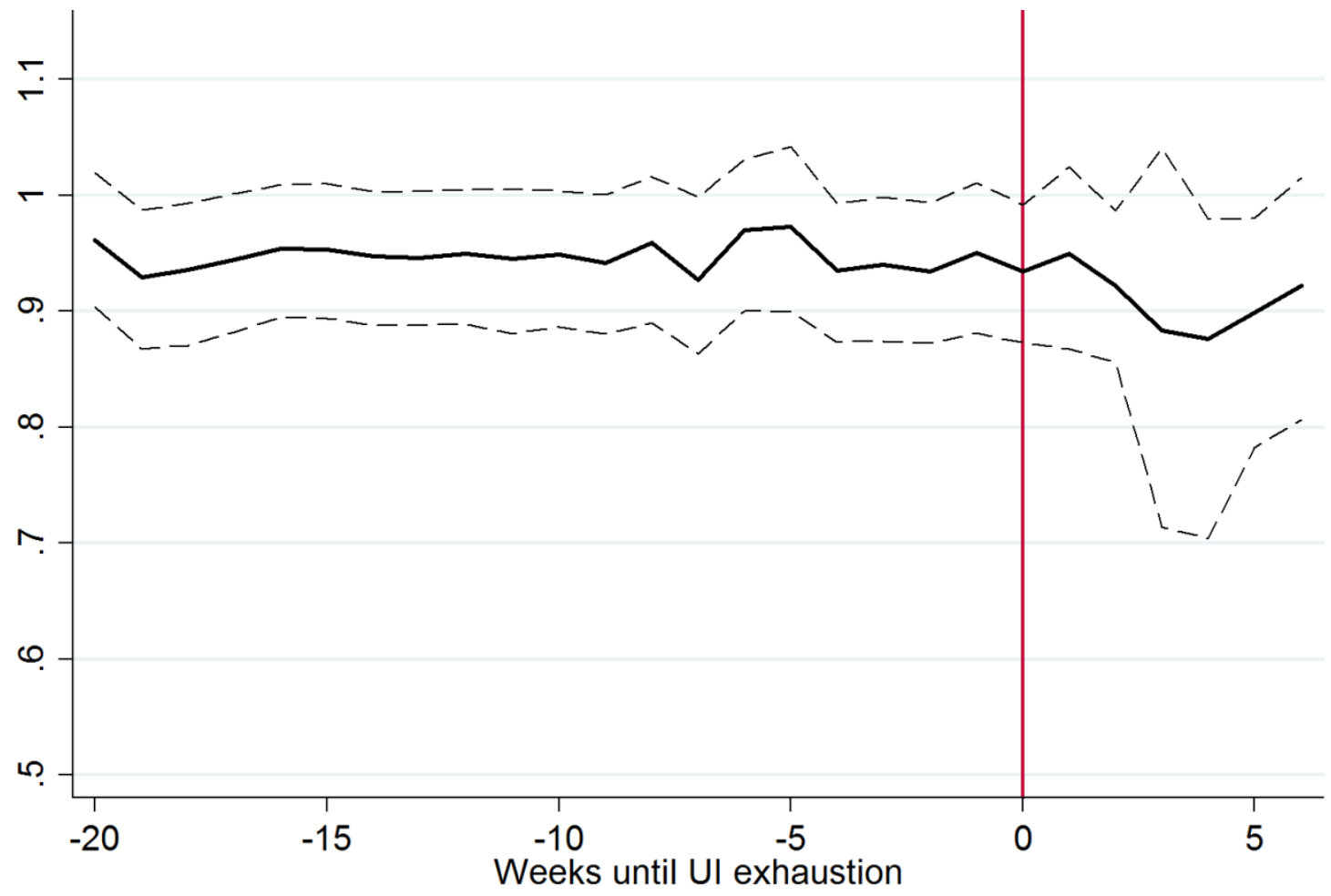

Universe: Unemployed; no job offer yet accepted; age 20-65.

Notes: To remove individual fixed effects, we estimated a regression of the reservation wage ratio on dummies indicating weeks until UI exhaustion and then plotted the estimated dummies normalized by the average fixed effect of those who have 20 weeks of UI left or less. The dashed lines show the $95 \%$ confidence interval, which was estimated by a bootstrap procedure with 5,000 draws. Universe: Unemployed; no job offer yet accepted; age 20-65. 
Figure 6: Histogram of the Individual Slope Coefficients of the Log Reservation Wage over the Spell of Unemployment

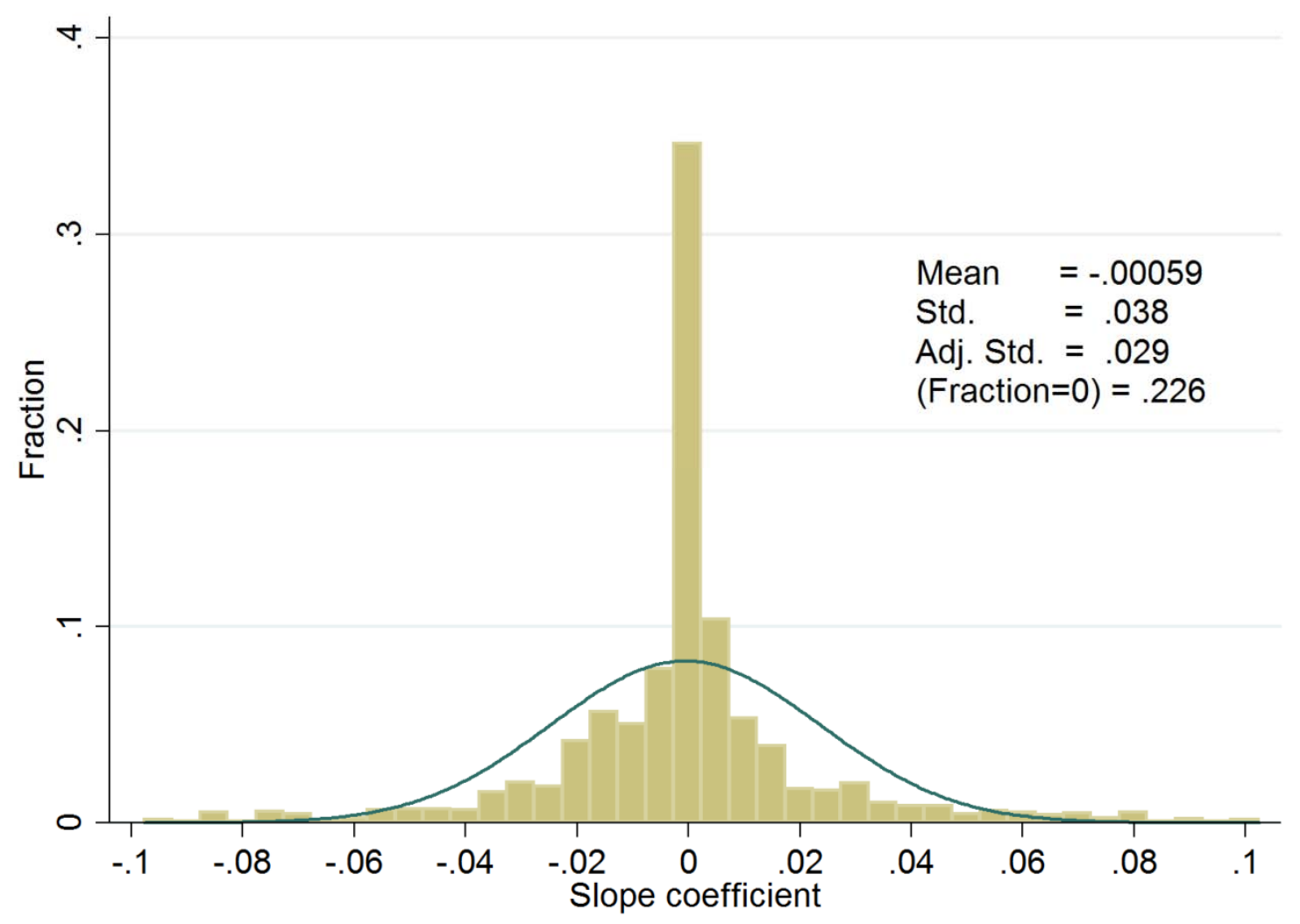

Notes: We restrict the sample to those individuals with 3 observations or more of the reservation wage. The blue line shows the normal density with the mean and (unadjusted) standard deviation of the individual slope coefficients. To adjust for sampling variability, we also report an adjusted standard deviation, where we subtract from the variance the average of the squared standard errors of the individual slope coefficients, and then take the square root. The individual slopes were derived from a regression of the log reservation wage on the duration of unemployment for each individual. The sample size is 2,690. 
Figure 7: LOWESS of Accepting a Job Offer on the Ratio of the Offered Wage to the

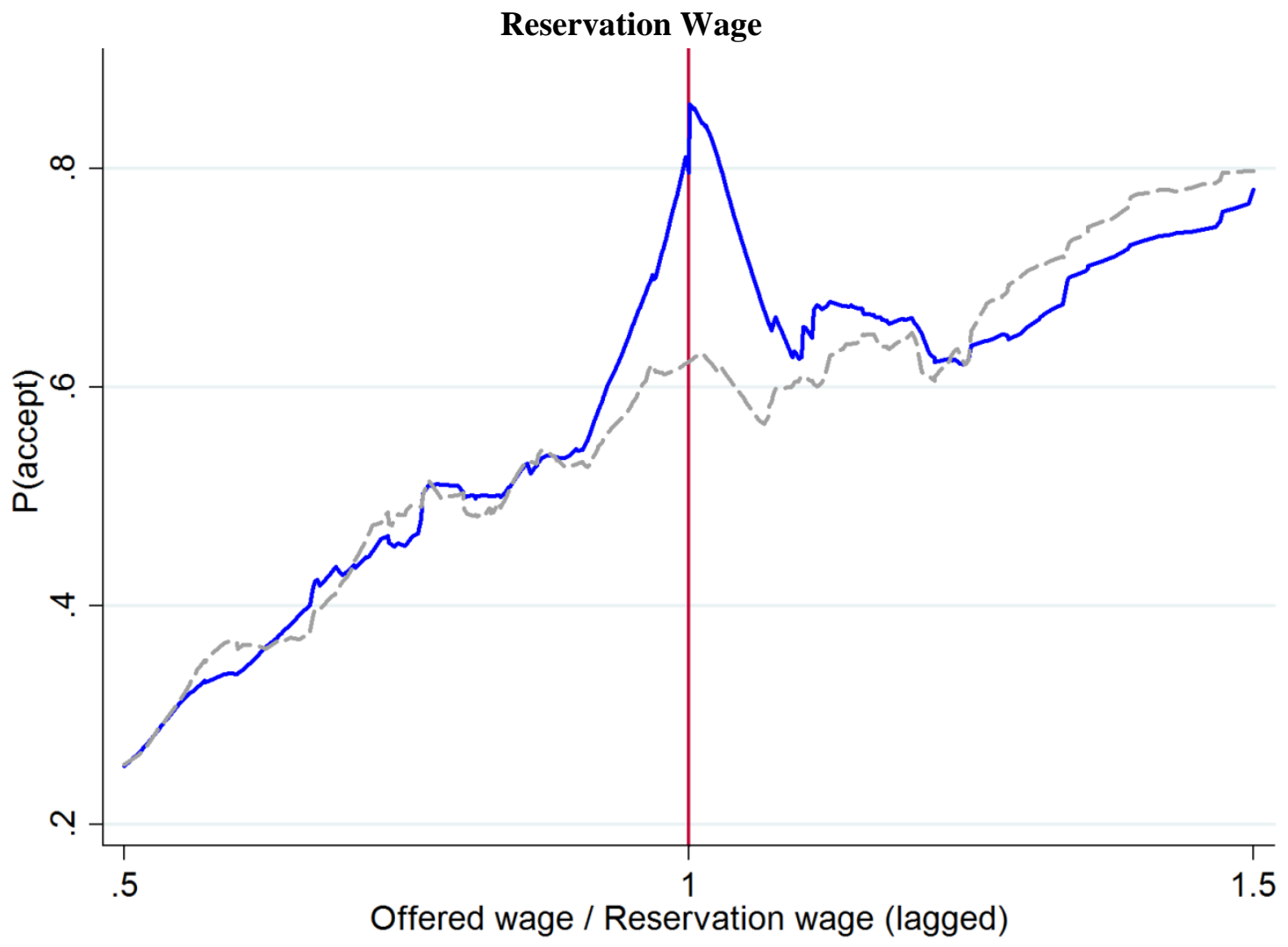

Notes: This graph shows the predicted value of a locally weighted regression (LOWESS) with bandwidth parameter 0.3 for a dummy of whether the job offer was accepted on the ratio of the hourly offered wage to the hourly reservation wage from the previous interview. The dashed line excludes observations where the offered wage equals the reservation wage. Sample: full-time offers, survey respondents aged 20-65. 
Figure 8: Histogram of the Ratio of the Offered Wage to the Reservation Wage

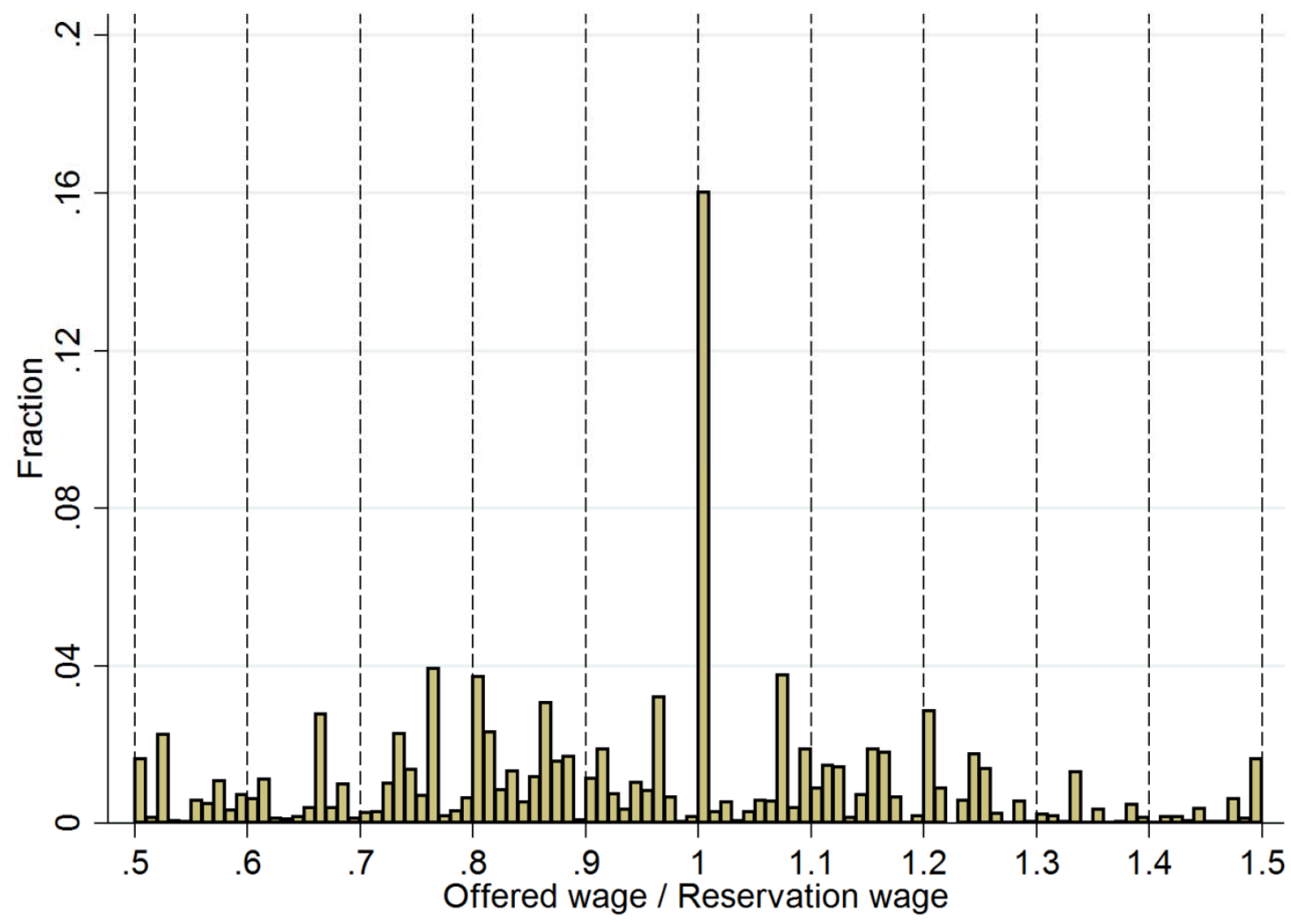

